\title{
New Waste Calcining Facility Non-Radioactive Process Decontamination
}

\author{
Michael C. Swenson
}

September 2001

Idaho National Engineering and Environmental Laboratory Bechtel BWXT Idaho, LLC 


\section{DISCLAIMER}

This information was prepared as an account of work sponsored by an agency of the U.S. Government. Neither the U.S. Government nor any agency thereof, nor any of their employees, makes any warranty, express or implied, or assumes any legal liability or responsibility for the accuracy, completeness, or usefulness of any information, apparatus, product, or process disclosed, or represents that its use would not infringe privately owned rights. References herein to any specific commercial product, process, or service by trade name, trademark, manufacturer, or otherwise, does not necessarily constitute or imply its endorsement, recommendation, or favoring by the U.S. Government or any agency thereof. The views and opinions of authors expressed herein do not necessarily state or reflect those of the U.S. Government or any agency thereof. 
INEEL/EXT-01-00879

\title{
New Waste Calcining Facility Non-Radioactive Decontamination
}

\author{
Michael C. Swenson
}

Published September 2001

\section{Idaho National Engineering and Environmental Laboratory High Level Waste Program Idaho Falls, Idaho 83415}

\author{
Prepared for the \\ U.S. Department of Energy \\ Assistant Secretary for \\ Environmental Management \\ Under DOE Idaho Operations Office \\ Contract DE-AC07-99ID13727
}




\section{ABSTRACT}

This report documents the results of a test of the New Waste Calcining Facility (NWCF) process decontamination system. The decontamination system est occurred in December 1981, during nonradioactive testing of the NWCF. The purpose of the decontamination system test was to identify equipment whose design prevented effective calcine removal and decontamination. Effective equipment decontamination was essential to reduce radiation fields for in-cell work after radioactive processing began. The decontamination system test began with a pre-decontamination inspection of the equipment. The pre-decontamination inspection documented the initial condition and cleanliness of the equipment. It provided a basis for judging the effectiveness of the decontamination. The decontamination consisted of a series of equipment flushes using nitric acid and water. A post-decontamination equipment inspection determined the effectiveness of the decontamination. The pre-decontamination and post-decontamination equipment inspections were documented with photographs. The decontamination system was effective in removing calcine from most of the NWCF equipment as evidenced by little visible calcine residue in the equipment after decontamination. The decontamination test identified four areas where the decontamination system required improvement. These included the Calciner off-gas line, Cyclone off-gas line, fluidizing air line, and the Calciner baffle plates. Physical modifications to enhance decontamination were made to those areas, resulting in an effective NWCF decontamination system. 


\section{SUMMARY}

This report documents the results of the non-radioactive test of the New Waste Calcining Facility (NWCF) process decontamination system. The test occurred in December 1981. The purpose of the test was to determine the effectiveness of the NWCF decontamination equipment. Previous experience in the Waste Calcining Facility (WCF) showed some equipment trapped calcine in areas that were inaccessible to decontamination techniques. The residual calcine generated high radiation fields for personnel who entered the process cells. Removing the calcine residue generated large quantities of waste (decontamination solution). The NWCF equipment design was an improvement over that of the WCF. The NWCF decontamination system test proved the effectiveness of the system and identified some system deficiencies. Modifications to those systems were made to improve the decontamination system before beginning radioactive operation.

The decontamination system test began with an extensive inspection of the process equipment following a Calciner shutdown during non-radioactive NWCF testing. Following the inspection, the Calciner equipment was decontaminated using nitric acid and water to remove calcine from the equipment. The equipment was inspected again following the decontamination. Photographs of the equipment were taken before and after the decontamination to document the test results. The effectiveness of the decontamination was based on the amount of visible calcine residue remaining in the equipment after the decontamination. In general, the decontamination was very effective, leaving virtually no visible calcine residue inside the equipment. The test identified four areas that required modifications to improve the decontamination system. They included the cyclone off-gas line, the Calciner off-gas line, the Calciner baffle plates, and the Calciner fluidizing air line. Modifications were made to each of these four areas before radioactive operation to improve the effectiveness of the decontamination system. 


\section{ACKNOWLEDGEMENTS}

The author acknowledges the role of Dennis Schmidt who was the cognizant engineer over the test of the NWCF decontamination system. Dennis kept records of the decontamination procedures and results that became the basis of this report. 


\section{CONTENTS}

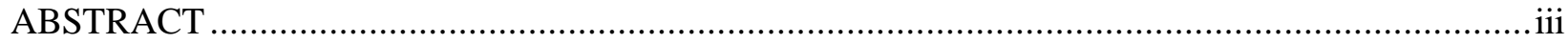

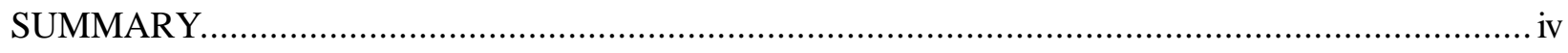

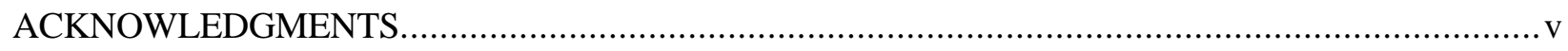

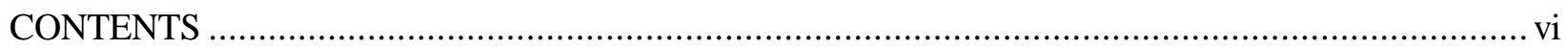

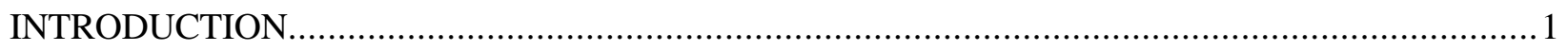

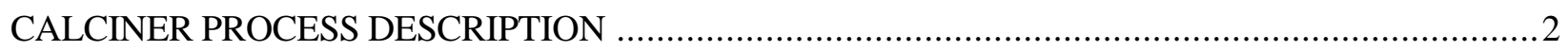

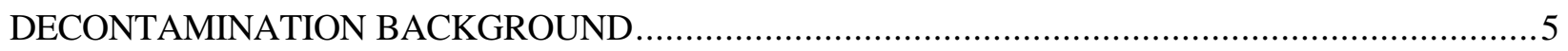

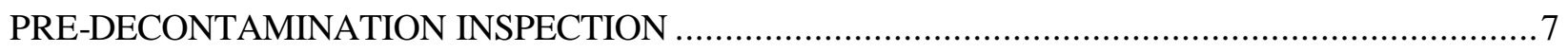

Feed System.

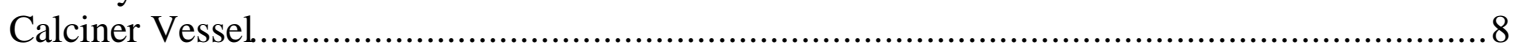

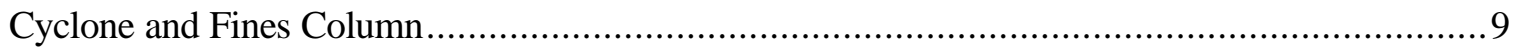

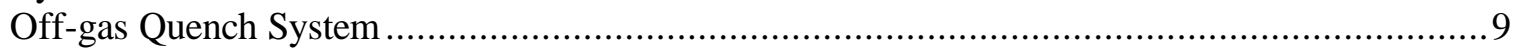

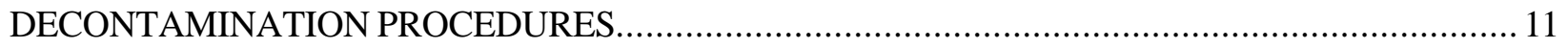

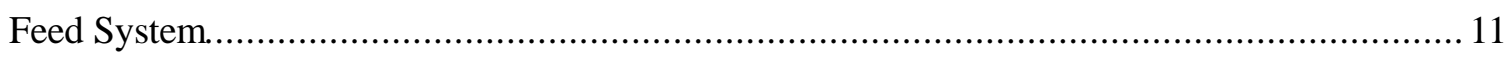

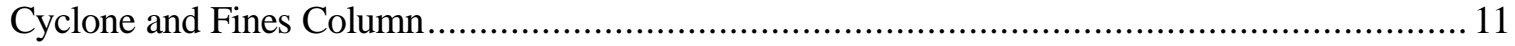

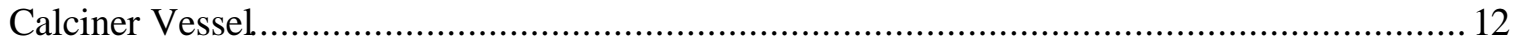

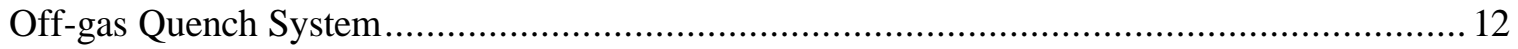

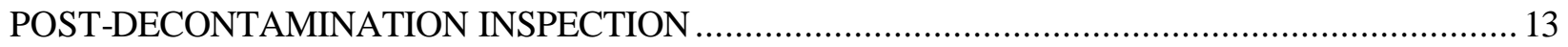

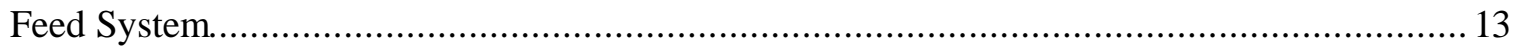

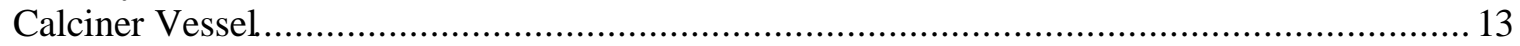

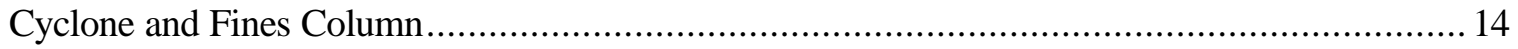

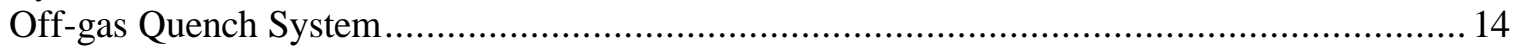

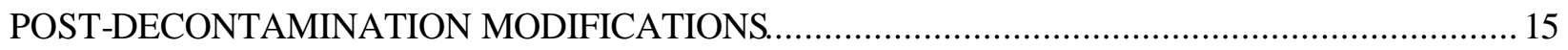

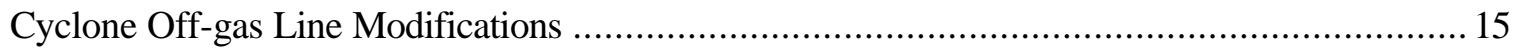

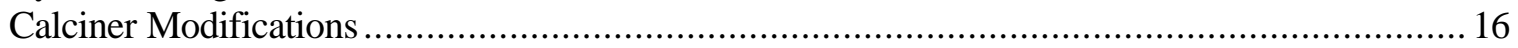

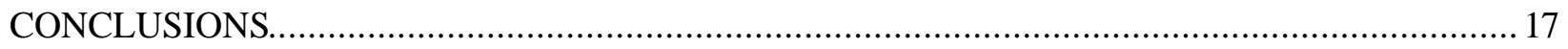

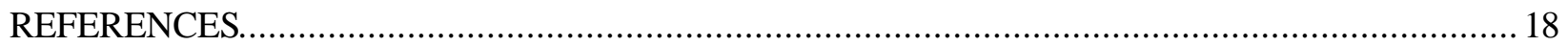

Appendix A- Pre-decontamination Photographs

Appendix B- Post-decontamination Photographs 


\section{FIGURES}

1. Simplified NWCF flow diagram $($ GZ00 0414) ................................................................. 3 


\section{NWCF SIMULATED DECONTAMINATION}

\section{INTRODUCTION}

This report documents the results of a test of the New Waste Calcining Facility (NWCF) decontamination system. The test occurred in December 1981, before radioactive operation began. The purpose of the decontamination test was to assure the design of the NWCF resolved problems inherent in the Waste Calcining Facility (WCF). In the WCF, the decontamination system could not effectively remove calcine from some of the process equipment. The calcine residue resulted in high radiation fields and doses to workers who entered the process cells. Removing the calcine residue generated large quantities of waste (decontamination solution).

The NWCF decontamination test included extensive inspections of the NWCF processing equipment before and after the decontamination. Photographs taken during the equipment inspections document the effectiveness of the decontamination. The photographs show significant amounts of calcine in some equipment before the decontamination. Generally, only small amounts of calcine residue remained after the decontamination. The decontamination test identified four areas that contained enough calcine after the decontamination to pose a radiological concern. Equipment modifications made to those areas improved the subsequent decontamination capability.

A few minor changes to equipment and procedures have been made since the decontamination test to enhance the decontamination process. For example, the residence time of decontamination solution in the process equipment is typically longer than that of the decontamination test. Experience showed extending the residence time of the decontamination solution increased the effectiveness of the decontamination. However, most of the NWCF process decontamination equipment and procedures are the same as in 1981. Thus, decontamination of the radioactive equipment should yield results (equipment cleanliness) similar to that of the 1981 test.

In 1981, extensive inspections of the NWCF processing equipment were performed before and after the simulated decontamination. Those inspections required a significant amount of in-cell work to access equipment. Since radioactive operations began, remote video inspections of limited portions of the process equipment have been done to confirm the effectiveness of the decontamination process. Extensive equipment inspections are not practical due to personnel radiation exposure and waste generation (decontamination solution) concerns.

Decontamination of the NWCF process equipment during radioactive operation has been successful. Equipment decontamination has removed calcine effectively enough to allow occasional cell entries by plant personnel to perform equipment repairs. The decontamination test helped reduce personnel radiation exposure and waste generation during radioactive operation. The decontamination test information may also be useful for facility decommissioning, when information on the amount of calcine residue in the NWCF can not be obtained due to radiological exposure and waste generation concerns. 


\section{CALCINER PROCESS DESCRIPTION}

The calcining process converts liquid radioactive waste into a granular solid (calcine) by evaporating the waste in the fluidized bed of the Calciner vessel. The calcining process converts the metals and fission products dissolved in the liquid into solid salts and oxides. The solid calcine is pneumatically transferred from the Calciner vessel to calcine storage bins.

The calcining process equipment is located in shielded cells in the NWCF (CPP-659). Figure 1 is a simplified flow diagram of the NWCF calcining process. Feed solution is transferred from the Tank Farm to the NWCF into a blend tank (VES-NCC-101) or one of two hold tanks (VES-NCC-102 and VESNCC-103). The blend and hold tanks are used to mix different waste types and to make chemical additions (aluminum nitrate, calcium nitrate, and boric acid) to the waste. Recycled solution from the offgas quench system is also added to the waste in the hold tanks.

A small feed tank (VES-NCC-104) receives feed solution from either hold tank via airlifts. Feed solution flows by gravity from the feed tank to the Calciner vessel (VES-NCC-105) through any of four parallel transfer lines. At the Calciner vessel, high-pressure air atomizes the waste and sprays it into the fluidized Calciner bed. The water in the feed solution vaporizes in the thermally hot fluidized bed. Dissolved solids in the waste form salts and oxides that build up in layers on the calcine bed particles. Periodically, calcine product is removed from the Calciner via one of two product removal lines to maintain proper bed level. A pneumatic transfer system transports the calcine to a calcine solids storage facility (CSSF).

The in-bed combustion of kerosene controls the Calciner bed temperature, historically at $500^{\circ} \mathrm{C}$. Kerosene is atomized with oxygen and sprayed into the hot, fluidized bed. There it burns to provide the heat required to evaporate the waste feed solution. Fluidizing air is supplied by one of two fluidizing blowers (BLO-NCO-205-1 and BLO-NCO-205-2). Electric heaters on the fluidizing air system provide heat to the Calciner during startup before initiating the in-bed-combustion of kerosene. The fluidizing air also removes water vapor and gaseous combustion products from the Calciner vessel.

The off-gas treatment portion of the calcining process removes small calcine particles entrained in the offgas. The upper, expanded portion of the Calciner vessel is the initial stage of the particulate removal system. The upper section of the Calciner has a set of baffles designed to remove the largest particles entrained in the offgas. After the Calciner, the offgas enters a high-efficiency cyclone (VES-NCC-107). The cyclone removes fine particles entrained in the offgas. The particles fall by gravity from the cyclone into the tall fines column, a cyclone disengaging leg. The particles drain from the fines column into the pneumatic transport system, which takes them with the calcine product to the CSSF. 


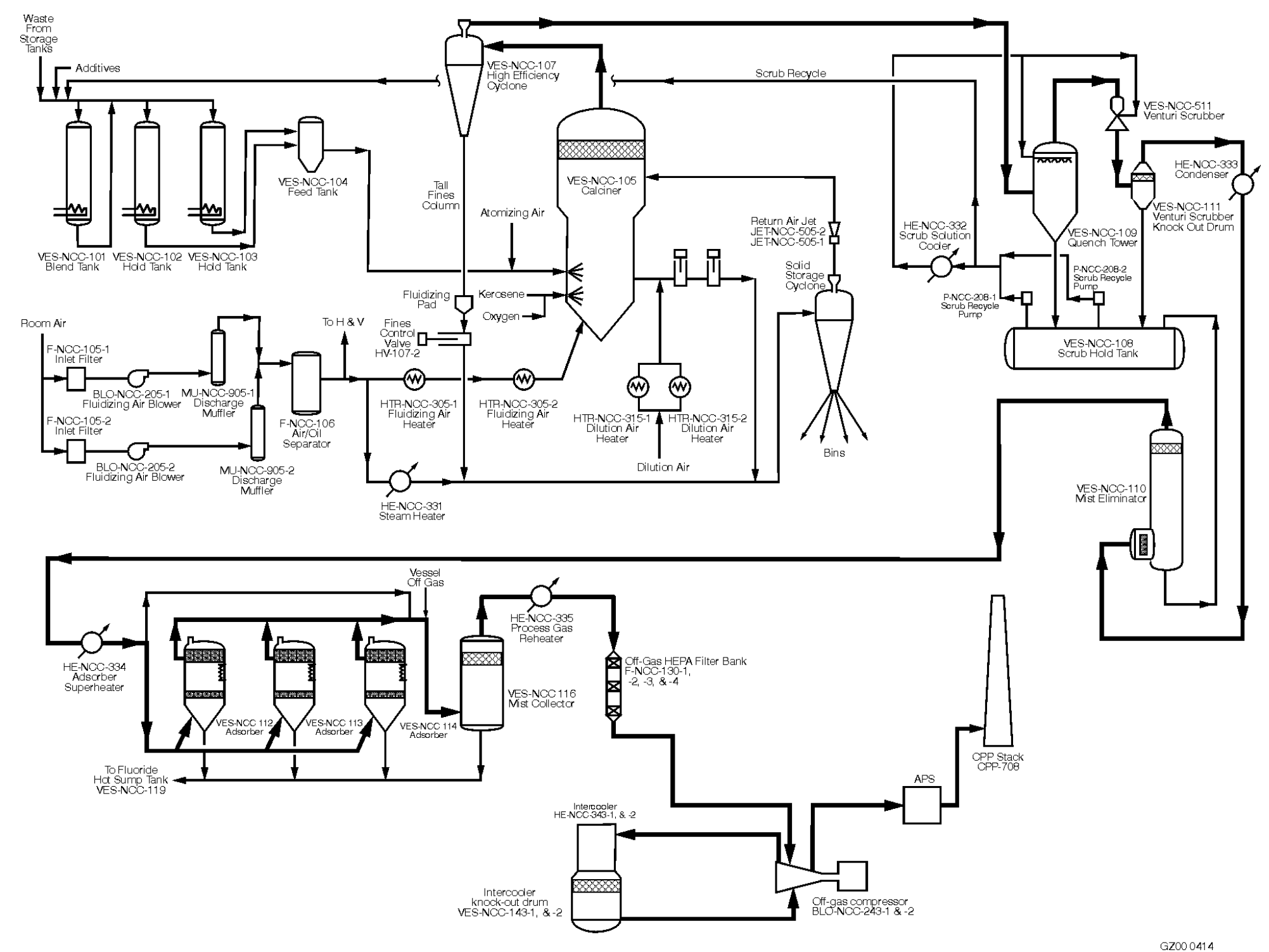

Figure 1. Simplified NWCF flow diagram (GZ00 0414). 
The Calciner offgas leaves the cyclone and enters the quench tower (VES-NCC-109). The hot offgas travels vertically up through the quench tower. The offgas is cooled to about $160^{\circ} \mathrm{F}$ by a solution of nitric acid sprayed downward through the quench tower, countercurrent to the offgas flow. The offgas then goes to a venturi scrubber (VS-NCC-511) where a nitric acid spray removes micron-sized particles. Following the venturi scrubber, a knockout drum (VES-NCC-111) removes fine mists and aerosols generated in the venturi scrubber. Solution from the quench tower and venturi scrubber drains by gravity to a quench solution hold tank (VES-NCC-108). One of two pumps (P-NCC-208-1 and P-NCC-208-2) circulates solution from the hold tank to the quench tower and venturi scrubber. Nitric acid, continuously added to the quench solution hold tank, dissolves the fine calcine particles removed from the offgas in the quench and scrubber systems. The volume of quench solution increases as acid is added to the hold tank. Periodically, a portion of the quench solution is transferred to the feed solution hold tanks, where it is mixed with Tank Farm waste and fed to the Calciner. Following the knockout drum, the offgas goes through a condenser (HE-NCC-333), normally not used, and a mist eliminator (VES-NCC-110), which contains two meshes in series to remove fine mists and aerosols. The mist eliminator meshes in vessels VES-NCC-111 and -110 become progressively finer to remove smaller and smaller mists and aerosols from the offgas.

Downstream of VES-NCC-110, the offgas goes through a superheater (HE-NCC-334), normally not used, and to one of three, parallel, ruthenium adsorbers (VES-NCC-112, VES-NCC-113, and VES-NCC-114). The adsorbers contain silica gel, designed to remove volatile ruthenium from the offgas. Although there is little volatile ruthenium in the offgas, the adsorbers also act as roughing filters upstream of the highefficient-particulate-air (HEPA) filters. Following the ruthenium adsorbers, the Calciner process offgas combines with the vessel offgas. The vessel offgas consists of gases such as instrument air, sparge (agitation) air, and vapor space gases discharged when a vessel fills with liquid. The vessel offgas comes from liquid storage tanks. It is not contaminated with calcine particles, so it bypasses the previously described Calciner off-gas clean-up equipment.

The combined Calciner process and vessel off-gas streams go through a mist eliminator (VES-NCC-116) and a superheater (HE-NCC-335), which increases the off-gas temperature to approximately $200^{\circ} \mathrm{F}$. The extra heat assures moisture in the offgas will not condense on the downstream HEPA filters. The superheated offgas then goes to four parallel banks of HEPA filters. Each filter bank consists of three stages of HEPA filters in series. Normally, two banks of filters are on line and two banks are normally in reserve in case the on-line filters require replacement.

Following the HEPA filters, the offgas enters one of two parallel gas compressors (BLO-NCC-243-1 and BLO-NCC-243-2). The compressors provide the motive force to maintain the Calciner off-gas system under a vacuum and send the offgas from the NWCF to a backup, off-gas treatment facility, the Atmospheric Protection System (APS). After treatment in the APS, the offgas is exhausted to the atmosphere via the main INTEC stack (CPP-708). 


\section{DECONTAMINATION BACKGROUND}

The NWCF was designed and built to replace the Waste Calcining Facility (WCF). Though similar in overall process design and function, the NWCF design incorporated several significant design improvements. One of the most significant improvements was the capability to perform remote maintenance work on failure-prone components such as valves, fuel and feed nozzles, etc. The WCF was primarily a hands-on maintenance facility. Most WCF maintenance work required personnel to enter a cell to repair or replace equipment. Equipment decontamination was required to reduce radiation fields prior to personnel entry into a cell. Equipment decontamination was sometimes difficult or ineffective due to equipment configurations that trapped calcine in areas inaccessible to decontamination efforts. The trapped calcine generated high radiation fields to personnel who entered the process cells. Attempts to remove the trapped calcine generated large amounts of liquid waste (decontamination solution). The NWCF remote-maintenance capability significantly reduced in-cell maintenance work and its accompanying waste generation and personnel radiation exposure. However, not all NWCF equipment was designed for remote maintenance and some decontamination and hands-on repair of the facility was anticipated. Simulated process equipment decontamination, performed before radioactive waste processing began, tested the effectiveness of the NWCF decontamination system.

The NWCF decontamination test was done in November and December 1981, during non-radioactive testing of NWCF. The purpose of the decontamination test was to verify the operability and effectiveness of NWCF decontamination equipment and procedures. The decontamination test was performed on the feed, calcination, and off-gas quench/scrubbing systems of the NWCF. It included most of the equipment in the blend-and-hold, Calciner, and off-gas cells. Equipment in other cells was not included in the simulated decontamination for a variety of reasons. The valve cubicle and filter cell had extensive remote maintenance capability, precluding the need for routine cell entries to do maintenance work. The equipment in the adsorber cell had no failure-prone equipment and there were no antic ipated entries into that cell. The equipment in the off-gas blower cell was expected to remain relatively clean because it was downstream of the Calciner off-gas cleanup equipment, including the high efficient particulate air (HEPA) filters. The systems selected for decontamination testing included the equipment where large amounts of calcine might remain following a process shutdown and the cells where in-cell maintenance work would be required.

The decontamination test began after a normal Calciner shutdown during non-radioactive test operation. A visual inspection of the process operating equipment was made before the decontamination. The equipment inspection used hands-on methods to remove manway and handhole covers to gain equipment access. Performing the inspection as a hands-on task was relatively easy before radioactive operation of the facility began. Performing the same inspection in a radioactive environment would result in large personnel radiation exposures and generate large quantities of decontamination wastes.

The Calciner equipment was decontaminated following the pre-decontamination inspection. Equipment was decontaminated using several nitric acid flushes followed by a water rinse. Following the decontamination, the equipment was inspected again. The effectiveness of the decontamination was determined by the amount of calcine residue visible in the equipment following the decontamination. Visible calcine residue was a sign of ineffective decontamination. Visible calcine residue would generate high radiation fields for in-cell workers after radioactive processing began. Equipment that was not effectively decontaminated was modified before radioactive operation to improve subsequent decontamination work. 
Photographs of the process equipment were taken during both the pre-decontamination and postdecontamination inspections to document the effectiveness of the decontamination. The inspection photographs are included as Appendices A and B of this report. This report also contans information (such as the equipment flushing procedures) from unpublished notes written by the engineer in charge of the decontamination test. ${ }^{\mathrm{a}}$

The equipment inspection photographs show the amount of calcine in the NWCF equipment before and after the facility decontamination. In general, the amount of post-decontamination calcine residue was very small. Unfortunately, photographs were not taken of all of the systems involved in the simulated decontamination. The primary purpose of the inspection photographs was to document the location and amount of residual calcine. Photographs were taken to document the presence of calcine, not the absence of calcine. The photographs were to help identify equipment that required modification to improve the decontamination system. Because of this philosophy, not all of the equipment was photographed during the inspections, especially if it was clean. Instead, the cognizant decontamination engineer simply noted there was no significant (visible) amount of residue in a particular location and moved forward with the inspection. Consequently, some vessels such as the cyclone (VES-NCC-107) were inspected, but not photographed because they were clean. In general, equipment that was not photographed was cleaner than the equipment that was photographed.

The decontamination test helped reduce radiation exposure and waste generation during subsequent radioactive operation of the NWCF. The test demonstrated the effectiveness of the decontamination system and identified equipment that required modification to enhance decontamination. Such equipment was modified and tested before radioactive operation began. The decontamination test information may also be useful in estimating the amount of calcine residue in the facility when detailed equipment examinations may not be possible.

\footnotetext{
${ }^{\text {a }}$ Unpublished report written by D. A. Schmidt shortly after the simulated NWCF decontamination.
} 


\section{PRE-DECONTAMINATION INSPECTION}

In December 1981, following the Calciner shutdown and before the test decontamination, several NWCF process vessels were inspected and photographed. The photographs (included as Appendix A) documented which equipment contained calcine and the approximate amount of calcine following a normal process shutdown. This inspection provided a baseline for comparison with a postdecontamination inspection to determine the effectiveness of the test decontamination. The inspection focused on the equipment where significant quantities of calcine were likely to remain. These included the feed, Calciner, cyclone, and quench systems.

\section{Feed System}

In the blend and hold cell, vessels NCC-102 (hold tank) and NCC-104 (feed tank) were inspected. Vessel NCC-102 is identical to vessel NCC-103 (hold tank), and very similar in configuration and service to vessel NCC-101 (blend tank). Because of the configuration and service similarities, vessel NCC-102 was considered representative of the three blend and hold tanks. It was inspected, but the other blend and hold tanks were not inspected. Vessel NCC-102 is a vertical cylinder (8 feet in diameter) with AMSE flanged and dished heads on both the top and bottom of the tank. Access to the interior of the vessel was via a manway on top of the vessel. The pre-decontamination inspection found the internal walls of NCC-102 were clean, with no visible solids on the vessel walls (see Figure A-1). However, a substantial amount of solids (up to four inches) was present in the nearly flat, dished bottom of the vessel. Analysis of the solids from the bottom of the vessel indicated they were high in alpha alumina.

Alpha alumina can form in the calcination process. It leaves the Calciner as fine particulate and is removed in the quench system. Alpha alumina is only slightly soluble in nitric acid and does not dissolve in quench solution as normal calcine does. The undissolved solids (UDS) were transferred to the feed system with recycled quench solution. The November 1981 non-radioactive Calciner operation was plagued with very high quantities of UDS in the quench system. This was due to the formation of alpha alumina in the Calciner and to the poor operation of the fines column. Poor operation of the fines column allowed the alpha alumina that should have been removed in the cyclone and fines column to enter the quench system. Quench solution UDS values during November 1981 often exceeded $100 \mathrm{~g} / \mathrm{L}$. By comparison, normal quench solution UDS values were 20 to $25 \mathrm{~g} / \mathrm{L}$ when processing high-level (fluoridebearing) waste, and less than $10 \mathrm{~g} / \mathrm{L}$ when processing sodium-bearing waste. During radioactive Calciner operation, the Calciner chemistry was controlled to prevent the formation of alpha alumina. In addition, the operation of the fines column was improved to prevent gross carryover of fines into the quench system. Thus, the amount of calcine residue (UDS) in the quench and feed systems during radioactive operation was less than that of the November 1981 test.

The Calciner feed tank (NCC-104) was inspected using a fiberoptic camera system. At the time, the feed tank was a small, vertical cylinder (2 feet in diameter) with semi-elliptical heads. The predecontamination inspection found about four inches of solids in the bottom of the feed tank (no pictures available from the fiberoptic system). Solids plugged the vessel drain line and accumulated to the level of the feed outlet lines. At that point, the solids reached an equilibrium level. Additional solids added to the vessel went with the feed solution to the Calciner, leaving a constant level of solids in the feed tank. The solids in the feed tank were identical to those in the hold tank, since that was the source of solution to the feed tank. Because of the solids accumulation problem, the original feed tank was replaced after the first 
radioactive waste processing campaign. The replacement tank has a conical bottom and air sparge system designed to reduce solids accumulation in the tank and aid in their removal.

\section{Calciner Vessel}

The Calciner vessel (VES-NCC-105) was inspected from three access points, the manway on top of the vessel, the upper east handhole (located just above the fluidizing air distributor), and the lower east handhole (located just below the fluidizing air distributor).

In the top of the Calciner, above the baffle plates, a thin layer of solids (less than ? inch thick) covered the interior surface of the Calciner (see Figures A2 and A-3). Calcine also collected in the joints between the baffle plate sections, on the upper surface of the baffle plates, and on the baffle support beams (see Figure A-4). Calcine filled the conical plug in the baffle plate inspection port (Figure A-5). There was also a layer of calcine approximately 1 inch deep in the short section of off-gas line between the Calciner and the cyclone.

Below the baffle plates, the amount of calcine on the vertical wall surface varied from virtually none to thin deposits around the feed nozzles and directly across from the transport air return line nozzle. The most significant amount of calcine found in the Calciner vessel was on top of the fluidizing air distributor plate. Figure A-6 is a view of the top of the distributor plate and the lower portion of the vessel walls. Figure A-6 shows the varying calcine deposits on the vessel walls. It shows calcine covering all horizontal surfaces including the thermowell (a 1-1/2 inch pipe that runs horizontally through the center of the vessel) and the fluidizing air distributor in the bottom of the vessel. Figure A-7 is a close-up view of a portion of the distributor plate. The amount of calcine on the fluidizing air distributor can be estimated using the Calciner internals as reference measurements. Several of the Calciner air distributor caps and their support legs are visible in Figures A-6 and A-7. The distributor plate has 36 conical shaped, air distributor caps. Each cap has three equally spaced support legs. The distributor caps are approximately 2-1/4 inches in diameter at the base. The top of the support legs is 2 inches above the distributor plate. Figures A-6 and A-7 show approximately two thirds of the support legs covered with calcine (at least 2 inches deep). The Calciner has a 1-inch sparge (agitation) ring that forms a circle inside the Calciner. The sparge ring is about 6 inches from the Calciner wall and 14 inches above the air distributor grid. The sparge ring is visible in Figure A-6 indicating the solids are below its elevation. Based on Figures A-6 and A-7, the calcine on the distributor plate had an average depth of 3 inches in December 1981 before the decontamination.

Figure A-8 is a picture of the calcine in the Calciner vessel following the non-radioactive operation of the Calciner in June 1982. Figure A-8 is not associated with the decontamination test of December 1981. It is included to illustrate the amount of calcine remaining on the distributor varies from one shutdown to another. There are no air distributor caps visible in Figure A-8, indicating there was more calcine present in June 1982 than in December 1981. However, the sparge ring is visible in Figure A-8, indicating the calcine is below the 14-inch level. The calcine on the distributor plate had an average depth of 6 inches in June 1982.

The pre-decontamination inspection found the upper east Calciner handhole (an 8-inch nozzle located just above the fluidizing air distribution grid) completely filled with calcine (see Figure A-9). The handhole is a non-fluidized area that collects calcine during Calciner operation. Normal shutdown procedures can not remove calcine from the handhole. Only vessel decontamination, using acid to dissolve the calcine, can 
remove calcine from such locations. The calcine in the east handhole was removed by hand during the pre-decontamination inspection to provide access into the vessel to continue the vessel internal inspection. The inspection found the handhole located on the west side of the vessel also filled with calcine. The calcine in the west handhole was left in place to judge the effectiveness of the subsequent calcine dissolution and decontamination effort.

The fluidizing air distribution plenum below the fluidizing air distribution grid had some fine calcine dust on portions of the plenum wall. A significant amount of calcine ( 1 inch deep) was in the bottom of the 8inch fluidizing airline where it joins the fluidizing air distribution plenum (see Figure A-10).

Calcine plugged the west product removal line during the non-radioactive test operation of the Calciner. Inspection of that line showed it to packed with calcine (see Figure A-11). The calcine was left in the line to determine the effectiveness of the decontamination effort.

\section{Cyclone and Fines Column}

The cyclone vessel (VES-NCC-107) and fines column, a solids disengaging leg connected to the bottom of the cyclone, were generally free of solids. The scouring action of the solids at high velocity kept the cyclone vessel clean. Very small amounts of calcine were on the cyclone walls in scattered locations. The calcine was generally at a surface irregularity such as a weld bead that shielded a small area of the vessel wall from the scouring action of the solids. Because there was virtually no calcine in the cyclone or fines column, no photographs of that system were taken.

The largest accumulation of solids observed during the entire pre-decontamination inspection was in the horizontal portion of the 16-inch off-gas line between the cyclone and the quench tower. Fine calcine dust covered the bottom of the visible portion of the line. The depth of solids was 3 to 4 inches in the bottom of the pipe (see Figure A-12). The solids depth appeared to be uniform throughout the length of off-gas line. However, only the first 7 feet of the 22 -foot horizontal line were inspected. An elbow in the line prevented the inspection of the last 15 feet. The off-gas line contained approximately 200 pounds of calcine dust ${ }^{1}$. Calcine partially filled the off-gas line during normal operation because the line was too large in diameter and the resulting off-gas velocity was too low to prevent solids deposition in the bottom of the pipe ${ }^{1}$.

The large accumulation of solids in the cyclone off-gas line was unexpected. Consequently, there was no decontamination method to remove the calcine from the off-gas line during the test. Instead, as much calcine as possible was removed by hand from the off-gas line during the pre-decontamination inspection. Modifications to the off-gas line were later made to the off-gas line to provide decontamination capability (see Post-Decontamination Modification section of this report).

\section{Off-gas Quench System}

The vessels in the off-gas cell were much cleaner than those in the Calciner cell. The off-gas cell houses the off-gas quench and scrubbing systems. The quench and scrubbing systems use a nitric acid solution to cool the hot Calciner offgas and remove fine particulate. Calcine is generally soluble in nitric acid. The combination of the solubility of calcine in acid, and the rinsing action of the quench solution in the off-gas cell vessels, prevented any accumulation of calcine in the off-gas system. The only visible calcine residue in the off-gas cell vessels were streaks and spots from quench solution that dried on the vessel walls after the quench solution circulation pumps were turned off. 
Figures A-13 through A-18 show the interiors of vessels in the quench and scrubbing systems before decontamination. Figures A-13 and A-14 show the interior of the quench tower (VES-NCC-109). Figure A-13 shows the liquid spray nozzles and off-gas outlet in the upper portion of the vessel. Figure A-14 shows the off-gas distributor plate in the lower portion of the vessel. Both photographs show light streaks of residue on the vessel walls from evaporated quench solution. There is no accumulation of calcine in the vessel.

Figures A-15 and A-16 show the interior of the venturi scrubber knockout drum (VES-NCC-111) before decontamination. Figure A-15 shows the upper portion of the knockout drum and its stainless steel mesh. Figure A-16 shows the lower portion of the knockout drum with its baffles and catch plate over the liquid drain line. The knockout drum is clean except for some streaks remaining from evaporated quench solution. The vessel walls and the mesh are free of accumulated calcine.

Figures A-17 and A-18 show the interior of the mist eliminator (VES-NCC-110) before decontamination. Figure A-17 shows the upper portion of the vessel and its outlet wire mesh. Figure A-18 shows the lower portion of the vessel and the catch plate over the liquid drain line. The mist eliminator was cleaner than the quench tower or knockout drum. It had less streaking on the vessel walls, and no calcine accumulation.

The quench solution hold tank (VES-NCC-108) is a 5-foot diameter, horizontal cylinder, and acts as a surge tank for quench solution. The tank does not have a bottom drain. Inspection of the quench hold tank revealed the vessel walls were free of solids, but there was a considerable amount of solids in the small quantity of solution remaining in the bottom of the tank. The solids did not form a hard cake. Instead, they were easily dispersed when the solution was agitated. Such solids are not difficult to remove with decontamination procedures designed to agitate and suspend the solids. The quench solution hold tank was the source of the solids found in the bottom of the feed system tanks. The solids were transferred to the feed system tanks with recycled scrub solution. 


\section{DECONTAMINATION PROCEDURES}

Decontamination procedures for the NWCF use techniques developed in the WCF. The primary decontamination technique uses the solubility of calcine in nitric acid. Most calcine (over 95\%) dissolves in nitric acid. Following a Calciner shutdown, most calcine can be removed from equipment by adding nitric acid to the equipment, allowing the calcine to dissolve, then draining the acid (containing dissolved calcine) from the equipment. Decontamination procedures also physically agitate the calcine residue, using vessel sparges, spray nozzles, and solution circulation to suspend any undissolved solids (UDS) in the decontamination solution. The suspended UDS are removed with the decontamination solution.

Decontamination techniques such as abrasion with inert material and dissolution of oxide films from vessel internals was effective in the WCF in removing trace amounts of calcine. Those techniques were not used during the NWCF decontamination test. The decontamination test was to show the installed decontamination equipment functioned properly, and to identify equipment inaccessible to any decontamination technique. The simulated decontamination procedures included one or more nitric acid (approximately 6 molar) flushes of equipment that contained large quantities of calcine. A water rinse followed the acid flushes to remove residual acid and prepare the vessels for the post-decontamination inspection. The following sections describe the acid and water flushes that comprised the decontamination test.

\section{Feed System}

The blend tank (NCC-101), two hold tanks (NCC-102 and NCC-103), and the feed tank (NCC-104) were cleaned in a two-step process. The first step consisted of adding acid to the blend and hold tanks and heating it for 12 hours to dissolve residual solids. In order to provide agitation and undissolved solids removal, the decontamination solution was circulated through the vessels. In the case of the blend tank, the solution went out the bottom of the tank, to an airlift, and back into the top of the tank. In the case of the hold tanks, solution went out the bottom of the tank, into an airlift, into the feed tank (NCC-104), and back to the top of the hold tank via the feed tank overflow line. Circulation of decontamination solution through the feed tank in this manner also decontaminated the feed tank. After draining the spent decontamination solution, the second decontamination step occurred. It was virtually the same as the first, except the circulation of decontamination solution used jets in each blend and hold tank instead of the airlifts. The circulation jets removed solution from near the bottom of the tank and discharged directly into the top of the tank.

The waste lines between the feed tank and the Calciner were flushed by draining decontamination solution through the lines from the feed tank to the Calciner vessel. This step occurred before the last Calciner flush to avoid contaminating the clean Calciner vessel with contaminated solution from the feed tank.

\section{Cyclone and Fines Column}

The decontamination of the cyclone and fines column preceded the decontamination of the Calciner vessel. The decontamination of the cyclone and fines column included the removal of calcine from the solids transport line. Part of the solids transport line also functions as the drain line for decontamination solution from the Calciner and cyclone. Experience at WCF showed less plugging of the Calciner liquid drain system occurred when the transport/drain line decontamination occurred before the Calciner 
decontamination. Cleaning of the fines column and solids transport line consisted of two 200-gallon nitric acid flushes. Acid was added to the system via the calcine solids transport system. Acid entered the fines column from the solids transport system through the valve on the fines column. Valves on the lines connecting the Calciner to the solids transport system were closed to prevent liquid from entering the Calciner.

\section{Calciner Vessel}

Decontamination of the Calciner vessel consisted of a series of five acid flushes. Valves connecting the fines column and Calciner with the calcine transport system were open during these flushes. Thus, because of the interconnecting calcine transport piping, the fines column and cyclone were cleaned again when the Calciner was decontaminated. The Calciner was flushed more frequently than other vessels because of the relatively large quantity of calcine it contained before the decontamination. The first Calciner flush added 150 gallons of acid to the fluidizing air plenum (conical portion on the bottom of the Calciner vessel). The acid addition was via the cyclone decontamination system, with the acid going into the cyclone, down the fines column, through the solids transport line, and up into the Calciner fluidizing air plenum. The acid in the Calciner plenum was heated using a steam sparge for 30 minutes and then drained. The acid for the second Calciner flush was also added via the cyclone/solids transport/fluidizing air plenum route. However, the second flush added enough acid to bring the liquid level in the Calciner to a height of 60 inches above the fluidizing air distributor. This corresponded to the normal operating level of calcine in the vessel. At that level, the acid covered the fluidizing air grid, the feed and fuel nozzles, the handholes, the product removal lines, and other areas where significant quantities of calcine were found in the pre-decontamination inspection. The solution was steam sparged for 30 minutes and then drained. The third flush was virtually identical to the second flush, the only difference being the steam sparge lasted six hours instead of 30 minutes. The method of decontaminating the Calciner by adding acid in increasing amounts via the bottom of the vessel was developed in the WCF. That method resulted in less drain line plugging problems than when the initial acid addition was via the top of the vessel. The fourth flush consisted of adding acid to the 60-inch level in the Calciner again. However, the acid addition was via the four decontamination spray nozzles located above the baffle plates in the top of the Calciner. The fourth flush was steam sparged for 24 hours and then drained. The fifth and final acid flush was a repeat of the third flush. The fifth flush was performed after decontaminating the feed system. The feed system decontamination included flushing the feed lines from the feed tank into the Calciner. The fifth Calciner flush removed any residue that drained into the Calciner from the feed line decontamination.

\section{Off-gas Quench System}

The off-gas quench and scrub system decontamination began by heating and sparging nitric acid in the scrub solution hold tank for 8 hours to dissolve solids in the tank. The decontamination solution in the hold tank was circulated through the off-gas quench system via each of the two normal flow paths for 8 hours each. The two flow paths were the route to the venturi scrubber and the route to the quench tower. The spent decontamination solution was drained, and the process repeated after adding fresh acid to the scrub solution hold tank. 


\section{POST-DECONTAMINATION INSPECTION}

The decontamination system was generally very effective. The post-decontamination inspection found most of the process equipment was clean with very little visible calcine residue. Post-decontamination photos (Appendix B) show the effectiveness of the decontamination process in removing calcine from the process equipment. Generally, post-decontamination photographs were taken of equipment that contained significant amounts of calcine before the decontamination to show the effectiveness (or ineffectiveness) of the decontamination. Consequently, areas that were relatively clean before decontamination were inspected, but not photographed unless calcine residue was found. Most of the post-decontamination photographs are of the Calciner. This is because the Calciner had most of the calcine before the decontamination, and it had most of the problem areas (residual calcine) after the decontamination. There are no post-decontamination photographs of most of the equipment because it was clean with little if any visible calcine residue. The cleanliness of the Calciner wall (as seen in Figure B-1) is representative of the interiors of the vessels that were inspected but not photographed.

\section{Feed System}

The feed system was decontaminated, but was not inspected afterwards. The decontamination process generated waste solution that had no ready disposal path. The waste solution was not radioactive so it was not sent to the PEW Evaporator or Tank Farm, the usual disposal paths for radioactive waste solutions. Instead, the solution was stored in the NWCF blend and hold tanks while disposal methods for the non-radioactive waste were developed. Storing the waste solution prevented an inspection of the feed system tanks. However, experience with the WCF feed system showed the NWCF decontamination method (circulating acid through the tanks) was successful in removing solids from the tanks. The two WCF hold tanks had a similar configuration to the three NWCF blend and hold tanks (vertical right cylinders with dished heads and a bottom drain). The waste solution processed at NWCF was also similar to that processed at NWCF. The WCF hold tanks were inspected as part of the WCF closure activities. The WCF hold tanks were free of visible solids ${ }^{2}$, validating the WCF and NWCF decontamination and solids removal technique. The NWCF simulated decontamination was successful in clearing the solids from the feed tank (VES-NCC-104) and clearing its drain line, adding to the confidence in the decontamination technique.

\section{Calciner Vessel}

With a few exceptions, the interior of the Calciner vessel was free of solids following the simulated decontamination. Figure B-1 shows the upper portion (above the baffle plates) of the Calciner interior, including a decontamination spray nozzle and the off-gas line exiting the vessel. Figure B-1 shows the interior of the vessel to be clean with virtually no visible calcine residue. A comparison of Figure B-1 with Figures A-2 and A-3 shows the effectiveness of the decontamination by the dramatic difference in cleanliness before and after the simulated decontamination. Figure B-2 is a view of the top of the baffle plates after decontamination showing them to be mostly clean (compare with Figures A-2 and A-4 for the pre-decontamination appearance of the baffle plates). Figure B-3 is a close-up photograph of the joints between baffle sections. Figure B-3 shows some calcine trapped in the joints between the baffle sections and on the support grid beneath the baffles. Figure B-4 shows the baffle plate inspection plug completely free of solids after decontamination. The pre-decontamination picture (Figure A-5) shows it filled with solids. Figure B-5 is a post-decontamination photograph of the top of the fluidizing air distributor plate. 
The west handhole that was filled with solids before the decontamination is visible on the opposite side of the vessel and is free of calcine. Figure B-5 shows scattered calcine residue on the distributor plate where several inches of calcine had been before the decontamination. The total amount of calcine residue on the distributor plate is very small, only a few hundred grams. Figure B-6 is a view of the fluidizing air distributor plenum beneath the grid plate. It shows the tee-connection between the 8inch fluidizing airline and the fluidizing air distributor plenum. The pre-decontamination photograph (Figure A-10) showed a significant amount of calcine in the bottom of the fluidizing airline. Figure B-6 shows most of that calcine is gone, and only a small amount of residue remaining in the bottom of the line.

\section{Cyclone and Fines Column}

The cyclone and fines column were relatively clean before the decontamination. They were clean after the decontamination except for residue transported into the system from the cyclone off-gas line. Most of the calcine dust in the cyclone off-gas line was removed by hand during the pre-decontamination inspection. However, some of the calcine dust remained in the off-gas line. Some decontamination solution from the cyclone spray nozzles entered the cyclone off-gas line, mixed with the calcine dust in the line, and ran down the wall of the cyclone, leaving a trail of residue. The cyclone off-gas line could not be decontaminated during the simulated NWCF decontamination. Decontamination capability was added to the cyclone off-gas line because of the decontamination system test (see Post-Decontamination Modification section of this report). The added capability to decontaminate the cyclone off-gas line eliminated any subsequent problem of off-gas line residue contaminating the cyclone.

\section{Off-gas Quench System}

The vessels in the off-gas scrub system were relatively clean prior to the decontamination effort (see Figures A13 through A18). They were even cleaner following the simulated decontamination. The drips and spots left by evaporated quench solution residue were rinsed away, leaving the vessels clean. Because of the cleanliness of the vessels before and after the decontamination, no post-decontamination photographs of the off-gas quench and scrubbing system vessels were taken. 


\section{POST DECONTAMINATION MODIFICATIONS}

The post-decontamination examination identified four areas where sufficient calcine residue existed to pose a significant radiological hazard to in-cell workers. Those areas were modified to enhance subsequent decontamination efforts. The four problem areas were the cyclone off-gas line, the Calciner off-gas line, the Calciner baffle plate support grid, and the fluidizing air line connection to the Calciner air distributor plenum.

\section{Cyclone Off-gas Line Modifications}

The most significant decontamination problem area was the 16-inch off-gas line between the cyclone and the quench tower. Approximately 200 pounds of fine calcine dust was in a horizontal, 22-foot section of the line (Figure A-11). That much calcine would generate a high radiation field to any workers in the upper part of the Calciner and off-gas cells ${ }^{3}$. The off-gas line originally had no installed means of removing the calcine. An extensive effort was made to design, test, and implement a decontamination system before radioactive processing began.

A full-scale mockup of the cyclone off-gas line was constructed in the pilot plant. The mockup was used to develop a method to remove calcine dust from the cyclone off-gas line. A series of decontamination spray nozzles was installed along the length of mockup pipe at 30-inch intervals. The nozzles were installed in the top of the pipe at a slight $\left(18^{\circ}\right)$ angle from vertical, pointing down the length of pipe. The nozzles were connected to the plant compressed air system. Procedures were developed to remove calcine from the bottom of the pipe using a series of 30-second air blasts via the spray nozzles. The air blasts began at the spray nozzle furthest down stream (nearest the quench tower in NWCF) and proceeded sequentially along the pipe using each nozzle. The effect of an air blast through a nozzle was to move calcine from the area beneath the nozzle to the area beneath the next downstream nozzle. The first nozzle (furthest downstream) removed calcine from the area beneath the nozzle and deposited it in an area that would be occupied by the quench tower in the NWCF. The second nozzle moved calcine from the area beneath it to an area beneath the first nozzle. The third nozzle moved calcine from the area beneath it to an area beneath the second nozzle. This continued along the entire length of line. Applying an air blast sequentially through each nozzle effectively moved the entire mass of calcine in the off-gas line one nozzle spacing (30 inches) down the line. The sequential air-blast procedure was repeated several times, until the calcine had been completely removed from the line ${ }^{4}$.

Based on the successful test of the calcine removal nozzles in the pilot plant, a similar system was installed in the NWCF. Twelve decontamination nozzles, similar to those tested in the pilot plant, were installed in the NWCF off-gas line between the cyclone and quench tower. The NWCF nozzle design differed slightly from the pilot plant design to further improve performance. For example, the NWCF nozzle spacing was 24 inches (reduced from the pilot plant spacing of 30 inches). In addition, the nozzles were connected to both a high-pressure air and a decontamination solution system, providing additional decontamination flexibility. The nozzles were successfully tested in the NWCF in August 1982, just before the start of radioactive Calciner operations ${ }^{5}$. The use of air alone removed most of the calcine from the off-gas line, leaving a thin film of dust inside the pipe. The thin film of dust was similar to that in the upper portion of the Calciner before decontamination. The December 1981 decontamination test demonstrated decontamination solution applied through spray nozzles could remove a thin calcine layer from the inside of the Calciner vessel. Because the liquid decontamination system had already been shown to be effective in the Calciner, decontamination solution was not used in the cyclone off-gas line to remove the remaining calcine residue. 


\section{Calciner Modifications}

The three remaining decontamination problem areas (all except the cyclone off-gas line) were associated with the Calciner vessel. These problem areas were far less significant than that of the cyclone off-gas line. Figures B-3 and B-6 show two of these problem areas (baffle plate grid support and the fluidizing airline) after the decontamination. Photographs of the Calciner off-gas line are not available. The photographs show a small amount (a few hundred grams or less) of calcine residue after the decontamination. During normal Calciner operation, the Calciner contains about nine thousand pounds (four million grams) of calcine. On a mass basis, the calcine visible in the problem areas in Figures B-3 and B-6 represent only a small fraction of a percent of the calcine normally in the Calciner. For example, 400 grams of calcine residue represents only one one-hundredth of one percent of the calcine in the Calciner during normal operation. However, even that amount of calcine could create a high radiation field for in-cell workers. Consequently, modifications were made to the facility to improve decontamination in those areas.

The Calciner off-gas line and the fluidizing air line had the same problem as the cyclone off-gas line. All three lines had horizontal sections of pipe where calcine settled and no installed means of removing the calcine. The Calciner off-gas and fluidizing air lines were modified in a manner similar to that of the cyclone off-gas line. Two decontamination nozzles were installed in each of the Calciner off-gas and the fluidizing air lines. The nozzles could remove calcine using either high-pressure air or decontamination solution. The cyclone off-gas line was the worst case (longest line, contained the most calcine, etc.) of the three horizontal lines that collected calcine. The successful pilot plant test and post-modification test of the worst-case (cyclone off-gas line) was considered sufficient representative testing for the Calciner off-gas and fluidizing air system modifications.

The post-decontamination calcine residue in the Calciner baffle plates was due to the design of the baffles and its support structure. The baffle plates are made of several sections that rest on a support grid in the Calciner vessel. Figure A-4 shows the top of the baffle plates with one of the baffle sections removed. The removed baffle section is lying on the other baffles. The baffle support grids are visible in the photograph. The baffle plate sections have sidewalls, which are visible in Figure A-4. There is a gap of ? to $1 / 4$ inch between the walls of adjoining baffle plate sections. During Calciner operation, calcine dust accumulated in the gaps between baffle sections. The baffle support beams trapped the calcine in the gaps by blocking the flow out the bottom of the gaps. The decontamination did not remove the calcine because the baffle support blocked the flow of decontamination solution between the baffle sections. The problem was resolved by installing spacers between the baffle sections and the support grid. The spacers raised the baffles above the support grid and provided a drainage path between the baffles and the support grid through which calcine and decontamination solution may flow. 


\section{CONCLUSIONS}

The non-radioactive test of the NWCF process equipment decontamination system was successful. The test demonstrated the decontamination system functioned properly by removing most of the visible calcine from the process equipment. The decontamination test revealed four areas where the decontamination was inadequate and left calc ine residue. Theses areas were the Calciner off-gas line, the fluidizing air line, the Calciner baffles, and the cyclone off-gas line. Equipment modifications such as the addition of decontamination spray nozzles and improved drainage paths were made to improve the effectiveness of decontamination techniques in these areas. The non-radioactive test decontamination and the subsequent equipment modifications to enhance the decontamination resulted in a properly functioning decontamination system.

Since the beginning of radioactive operation in 1982, the Calciner has had several radioactive operating campaigns and subsequent shutdowns. During those shutdowns, there have been several system decontaminations and cell entries by personnel to perform maintenance activities. The decontamination system has proven effective in removing calcine from the equipment to minimize worker radiation exposure and waste (decontamination solution) generation.

Since 1982, minor changes to the decontamination equipment and procedures have been made to further improve the effectiveness of the equipment decontamination process. These changes include longer "soak times", when the decontamination solution (typically nitric acid) resides in vessels to dissolve residual calcine. The four decontamination spray nozzles in the upper portion of the Calciner were originally connected to a single common decontamination solution supply line. That system was modified so that each of the four nozzles has its own supply line to assure decontamination solution gets to each nozzle and a single system plug or failure won't disable the entire system. Although there have been minor modification to the decontamination system, most of the equipment and procedures are the same as those tested in 1981. The excellent decontamination record of the facility during radioactive

processing has shown the value of the 1981 system test and has shown the radioactive decontamination results (vessel cleanliness) to be similar to that of the system test. 


\section{References}

1. S. S. Bodner, letter Bod-1-82 to K. F. Childs, "NWCF Off-Gas Line Fines Accumulation Evaluation", dated January 19, 1982.

2. K. E. Archibald/R. L. Demmer, letter KEA-24-95/RLD-6-95 to M Howard, "WCF Volume Calculations", dated August 17, 1995.

3. G. W. Hogg, letter Hogg-47-82 to D. L. Condotta, "NWCF Off-Gas Line Meeting", dated July 13, 1982.

4. R. A. Kirkbride, letter RAK-3-82 to K. F. Childs, "NWCF OFF-Gas Line Fines Removal Nozzle Test", dated March 1, 1982.

5. R. A. Kirkbride, letter Kirk-5-83 to A. P. Hoskins, "NWCF Off-Gas Line Cleanout", dated April 28, 1983. 


\section{Appendix A}

\section{Pre-decontamination NWCF Photographs}




\section{Appendix A}

\section{Pre-decontamination NWCF Photographs}

Figure A-1. Interior of feed hold tank (VES-NCC-102) prior to decontamination ..............................2

Figure A-2. Upper portion of Calciner (VES-NCC-105) prior to decontamination............................

Figure A-3. Upper portion of Calciner prior to decontamination .............................................

Figure A-4. Calciner baffle plates prior to decontamination .......................................................

Figure A-5. Calciner baffle plate inspection plug prior to decontamination ................................ 6

Figure A-6. Calciner fluidizing air distribution plate prior to decontamination ............................ A-7

Figure A-7. Calciner fluidizing air distribution plate prior to decontamination ........................... A-8

Figure A-8. Calciner fluidizing air distribution plate prior to decontamination ...............................A-9

Figure A-9. Calciner east handhole prior to decontamination .................................................... A-10

Figure A-10. Calciner fluidizing air distribution plenum prior to decontamination ......................... A-11

Figure A-11. Calciner west product removal line prior to decontamination .................................. A-12

Figure A-12. Cyclone (VES-NCC-107) off-gas line prior to decontamination ................................ A-13

Figure A-13. Upper portion of quench tower (VES-NCC-109) prior to decontamination ................. A-14

Figure A-14. Lower portion of quench tower prior to decontamination........................................ A-15

Figure A-15. Upper portion of knockout drum (VES-NCC-111) prior to decontamination ................ A-16

Figure A-16. Lower portion of knockout drum prior to decontamination .................................... A-17

Figure A-17. Upper portion of mist eliminator (VES-NCC-110) prior to decontamination ................. A-18

Figure A-18. Lower portion of mist eliminator prior to decontamination ................................... A-19 


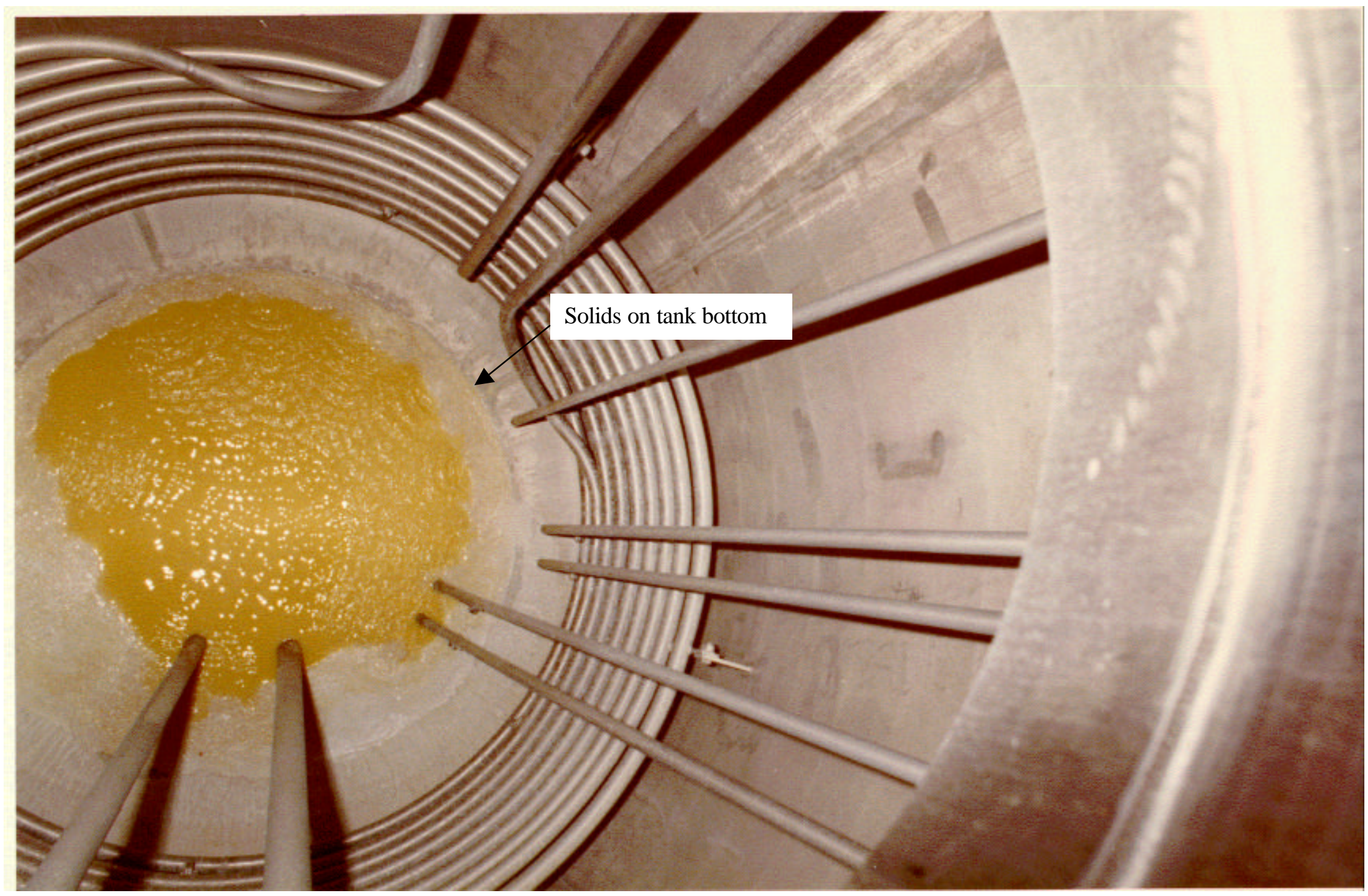

Figure A-1. Interior of hold tank VES-NCC-102 prior to decontamination. There are no solids on vessel wall, but there are solids in the bottom of the vessel (81-5552). 


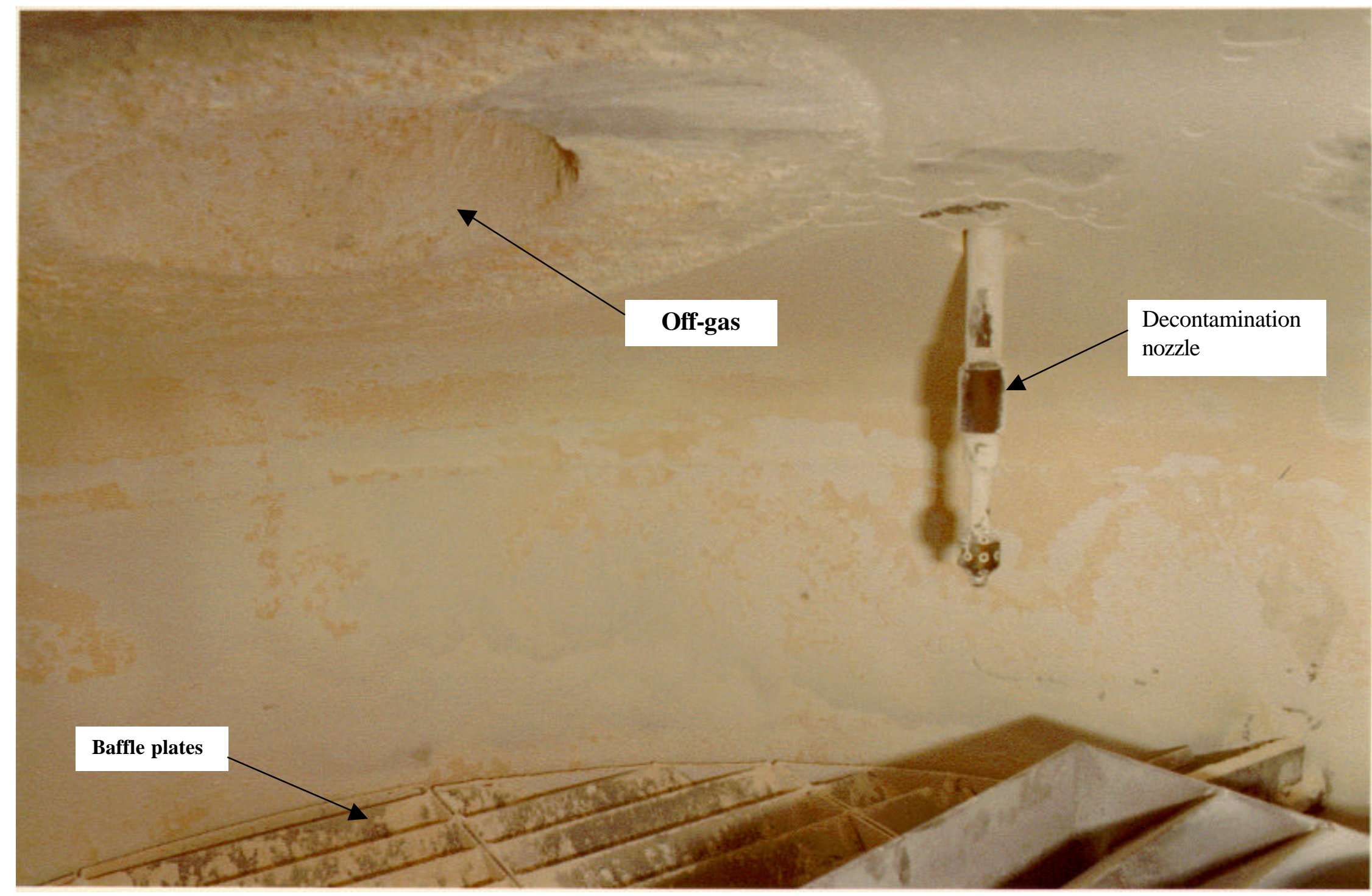

Figure A-2. Calcine-covered interior of the upper portion of the Calciner (VES-NCC-105), off-gas line, and baffle plates before decontamination (81-5590). 


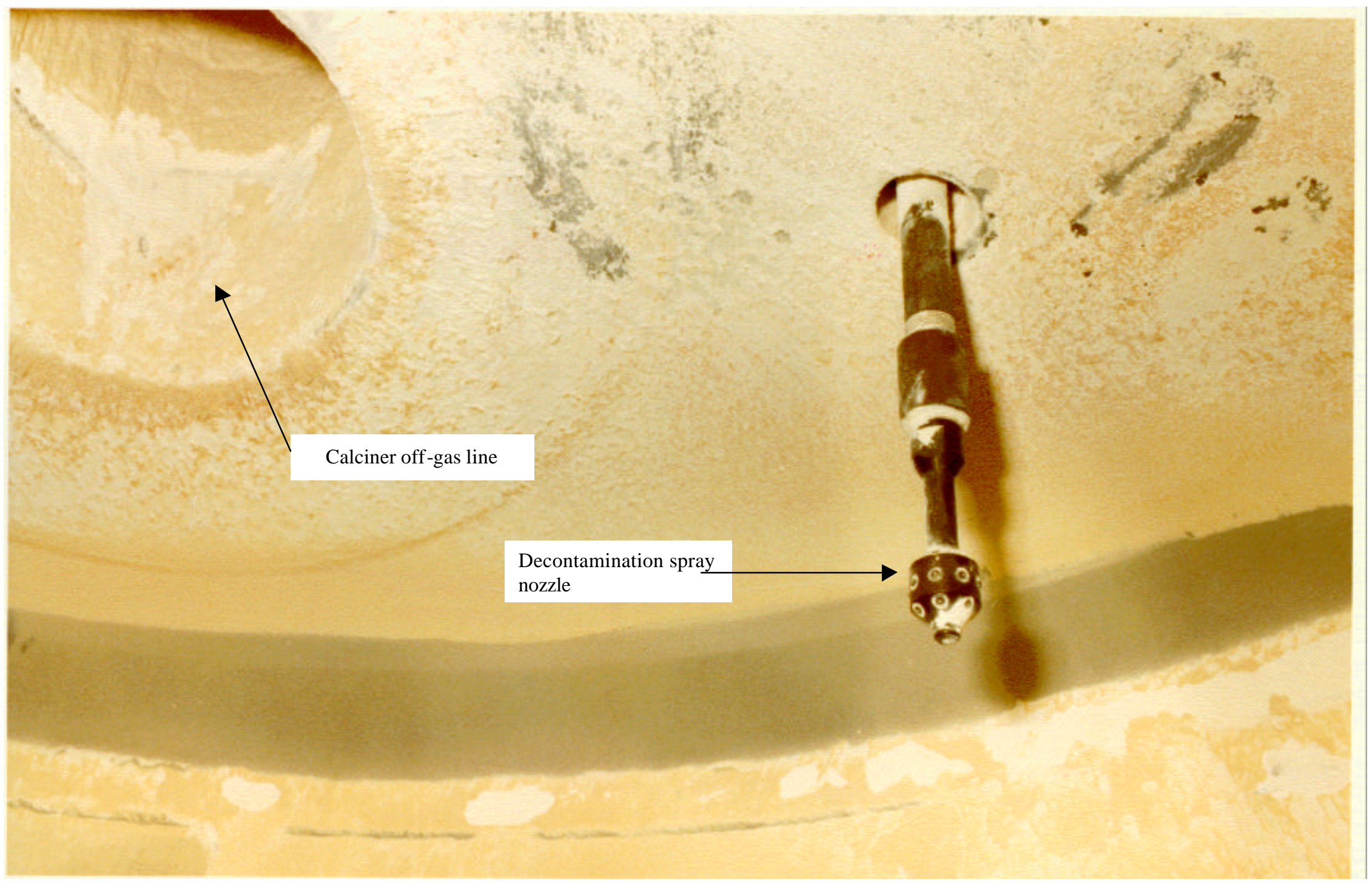

Figure A-3. Calciner-covered interior of the upper portion of the Calciner (VES-NCC-105) and off-gas line before decontamination (82-4812). 


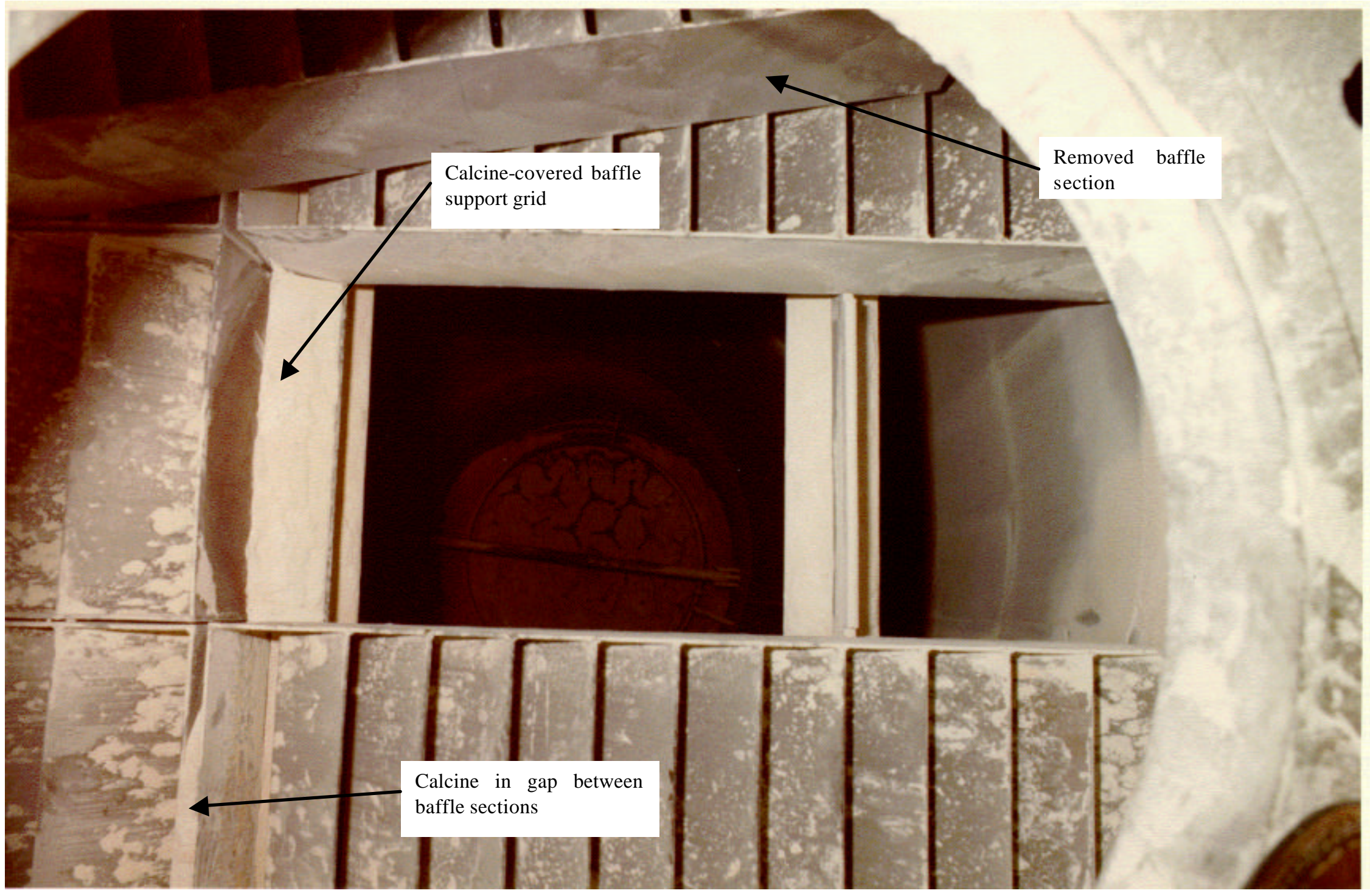

Figure A-4. View of the top of the Calciner baffle plates before decontamination. One section of the baffles has been moved, leaving a hole through which the baffle support grid can be seen (81-5591). 


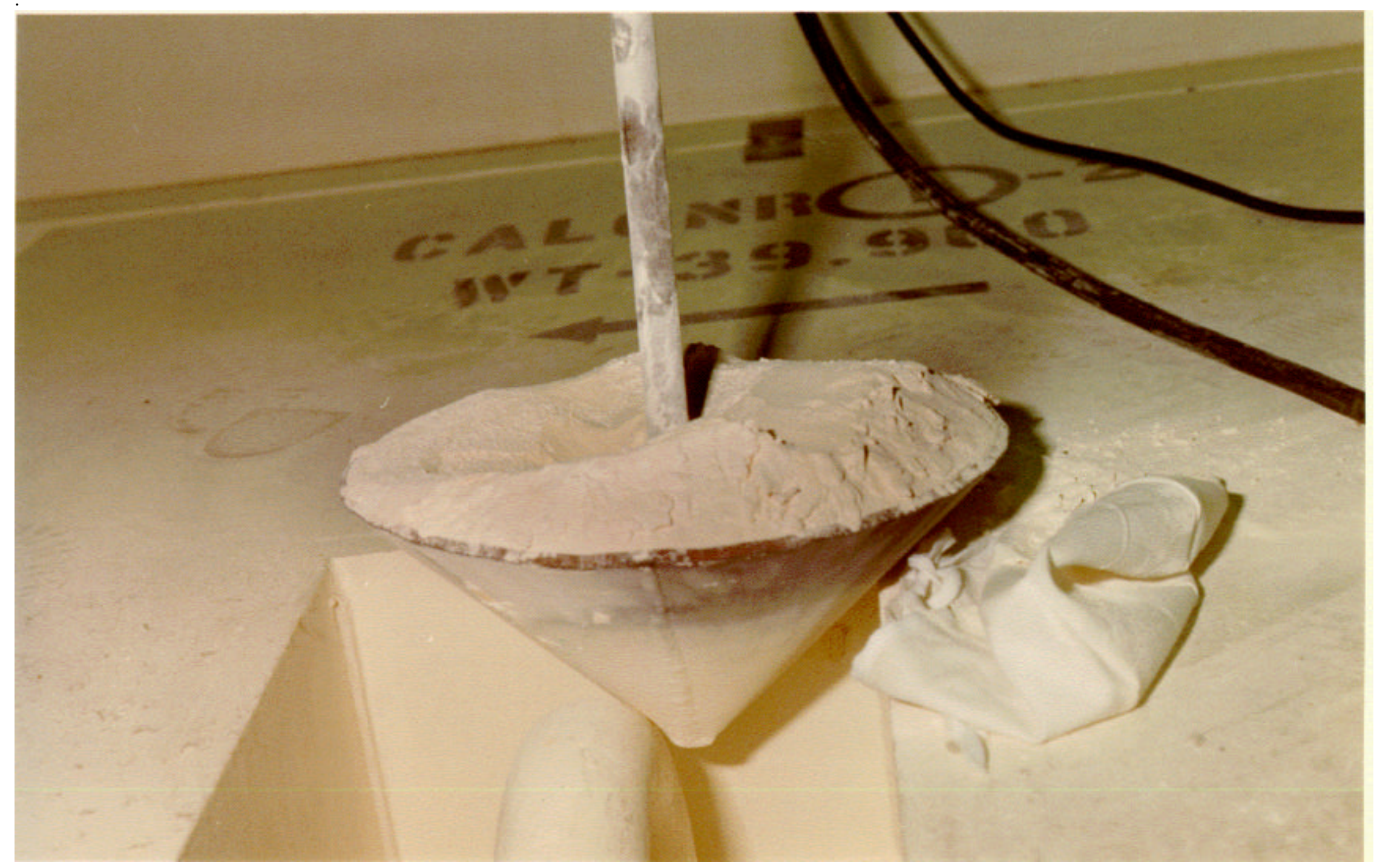

Figure A-5. Calciner baffle inspection port plug filled with calcine before decontamination (81-5584). 


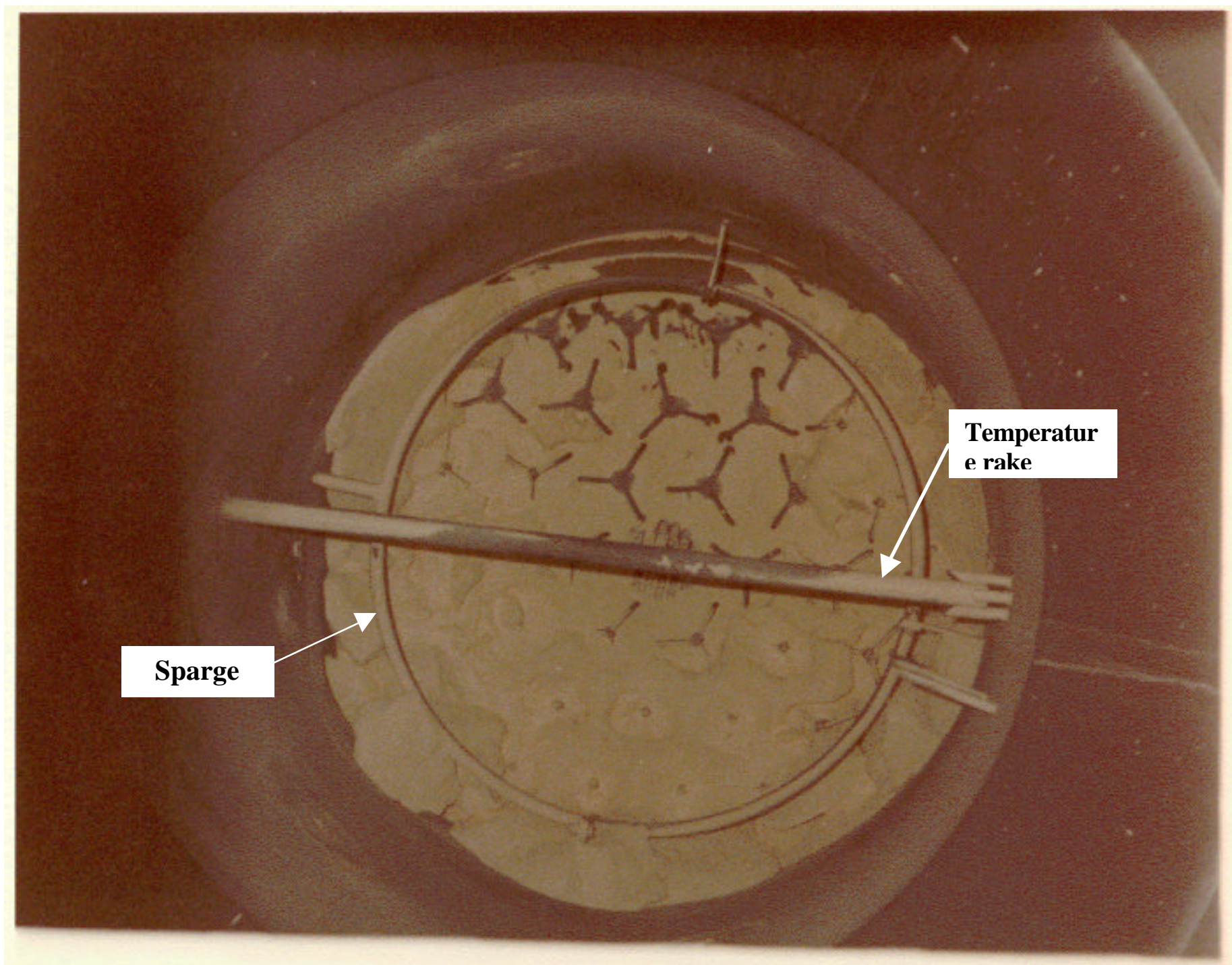

Figure A-6. Calcine-covered fluidizing air distributor plate in VES-NCC-105 before decontamination. The circular sparge ring (located 14 inches above the grid) and the horizontal thermowell (temperature rake) extending through the center of the vessel are visible (81-5594). 


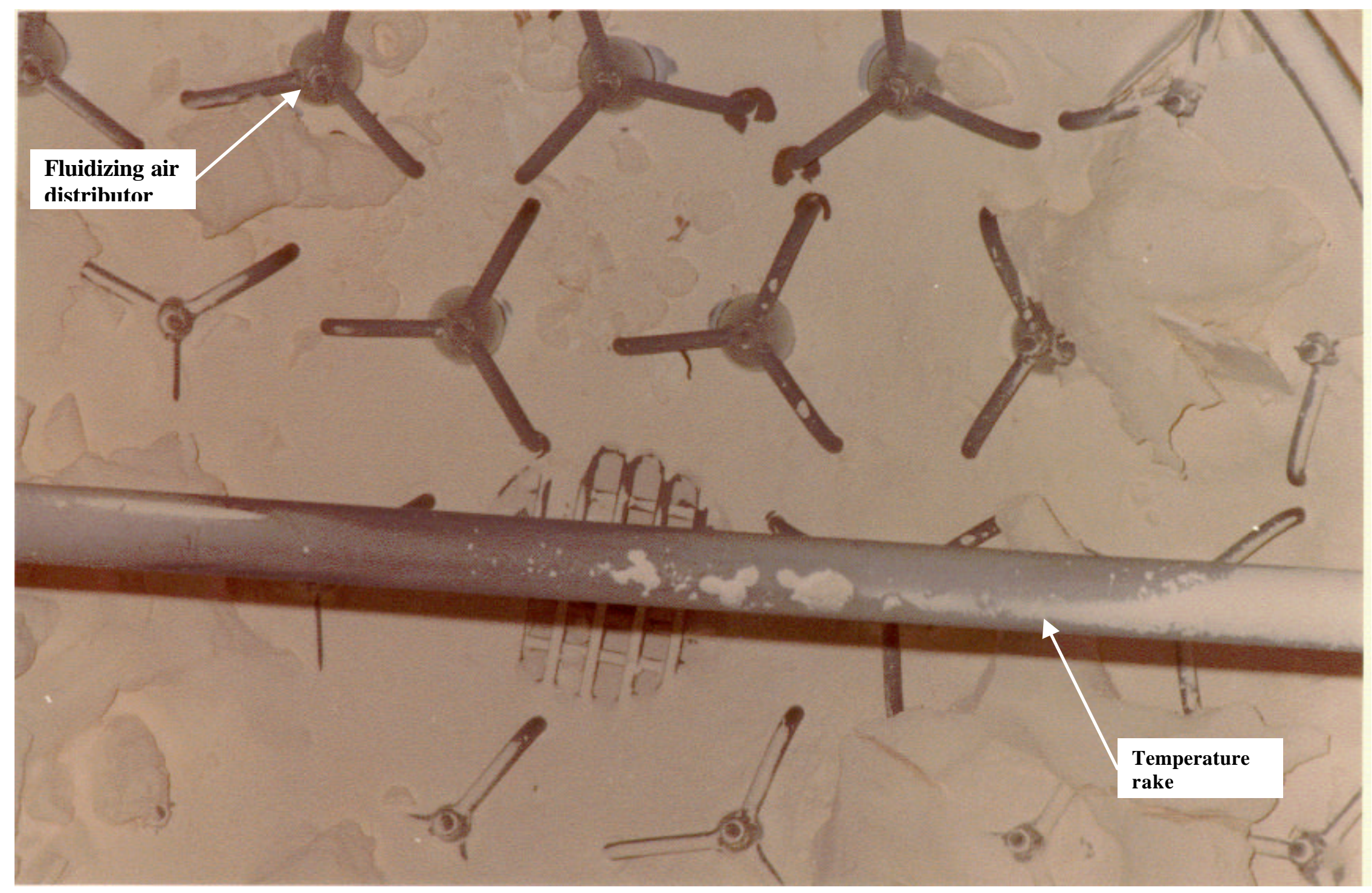

Figure A-7. Close-up view of calcine on top of fluidizing air distributor plate prior to decontamination. Several fluidizing air distributor caps with their three support legs are visible and others are covered with calcine. Varying amounts of calcine cover the distributor caps (81-5593). 


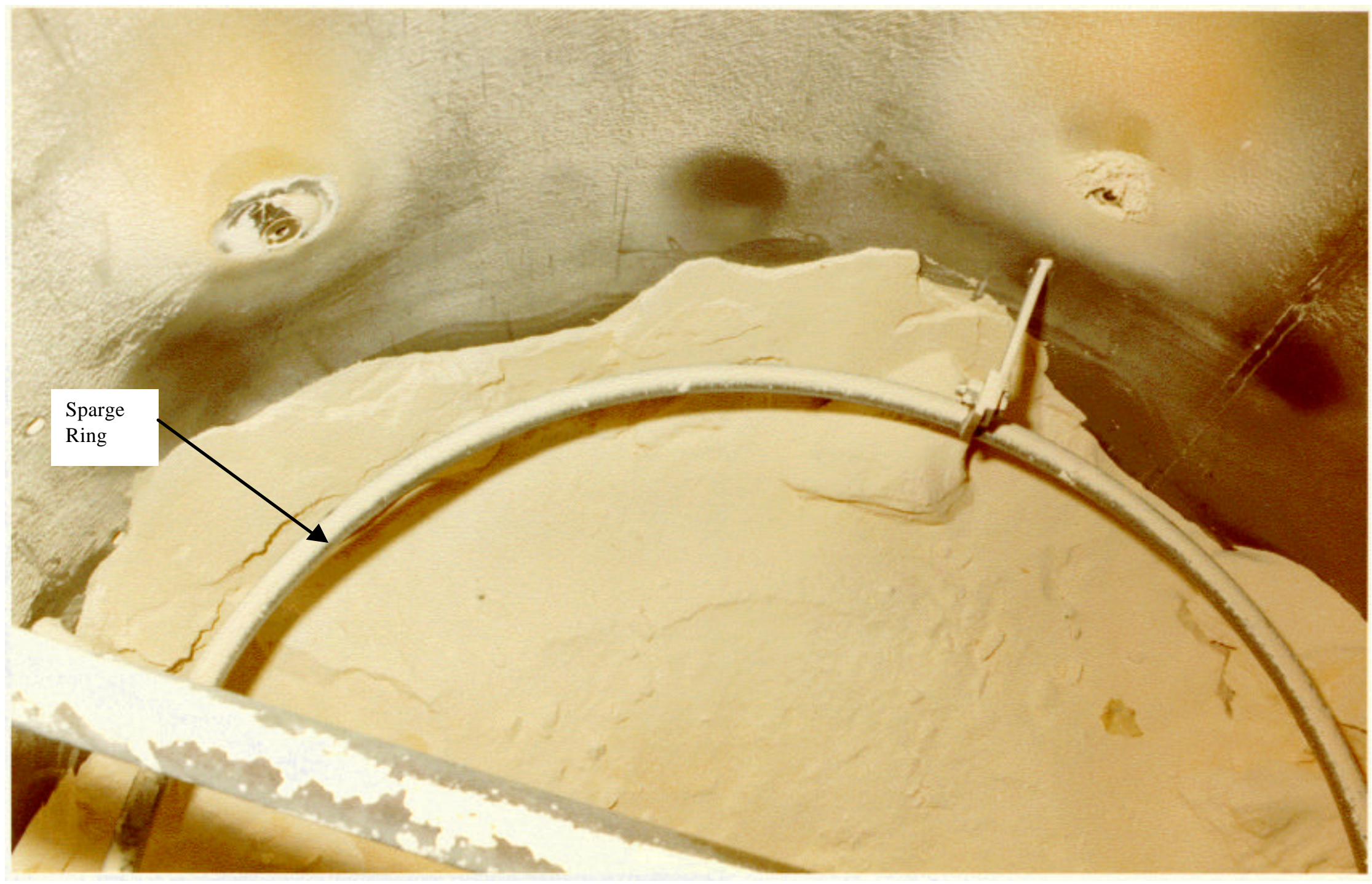

Figure A-8. View of the calcine remaining on the fluidizing air distributor plate following the June 1982 shutdown and before any decontamination. The Calcine remaining on the distributor completely covers the fluidizing air distributor caps, but the sparge ring is visible above the calcine (82-4803). 


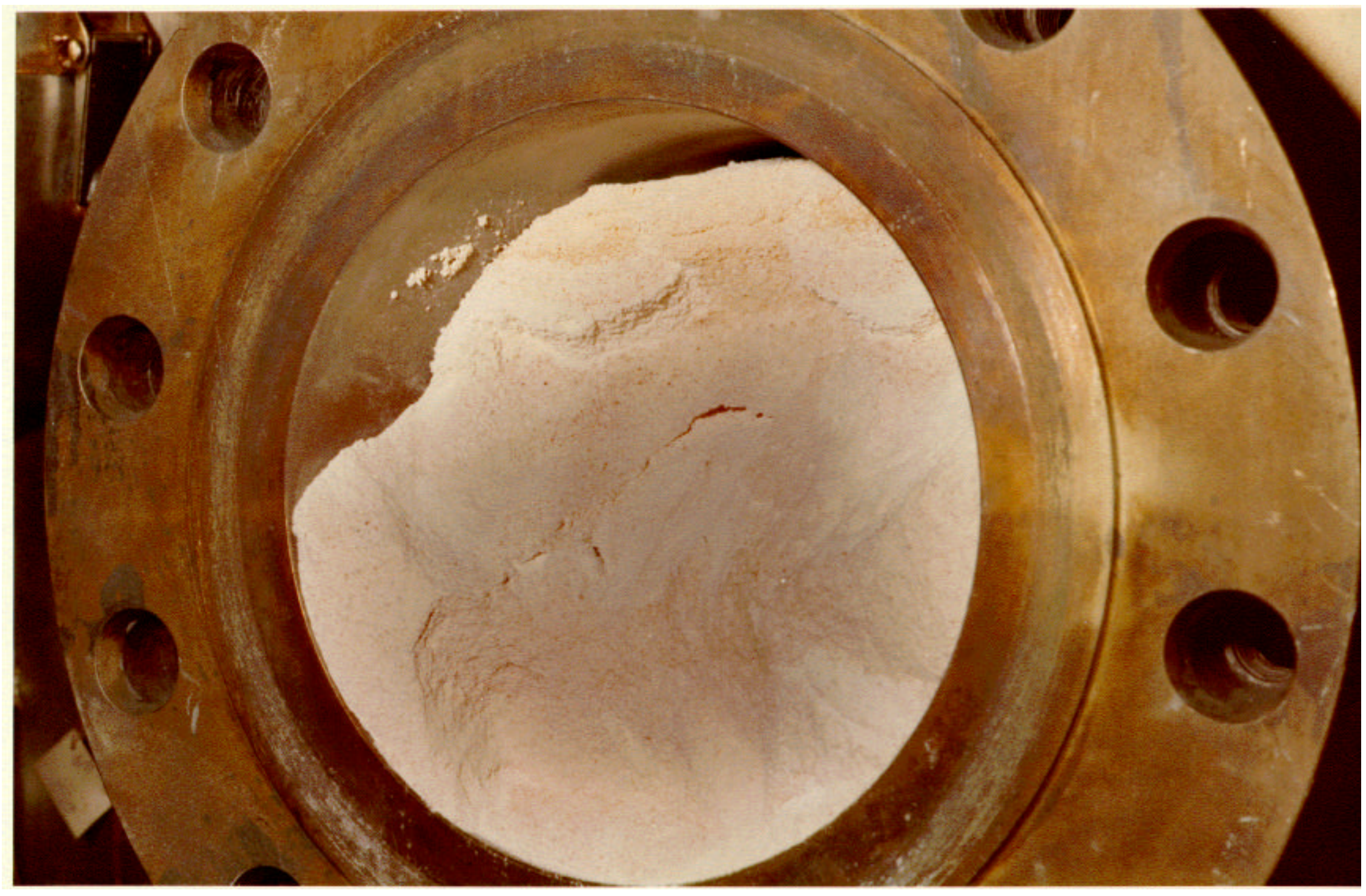

Figure A-9. Calciner east handhole (8-inch nozzle) located just above the fluidizing air distributor plate filled with calcine prior to decontamination (81-5579). 


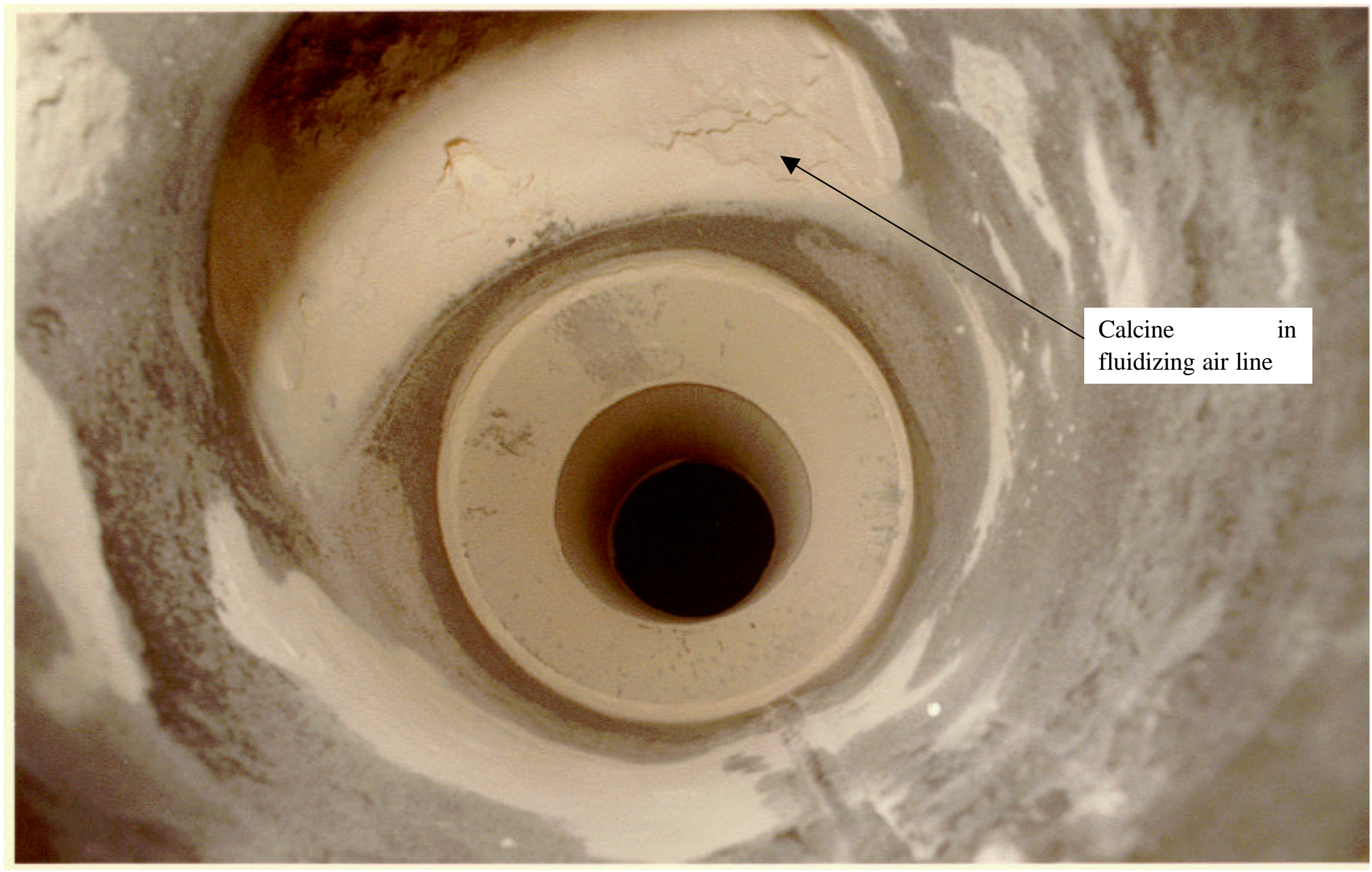

Figure A-10. Calciner fluidizing air plenum with a significant quantity of calcine in the fluidizing air line prior to decontamination. The 8 -inch fluidizing airline joins the plenum in a tee connection in the upper left hand portion of the photo. The dark hole in the center of the picture is the plenum drain line ( 81 5547). 


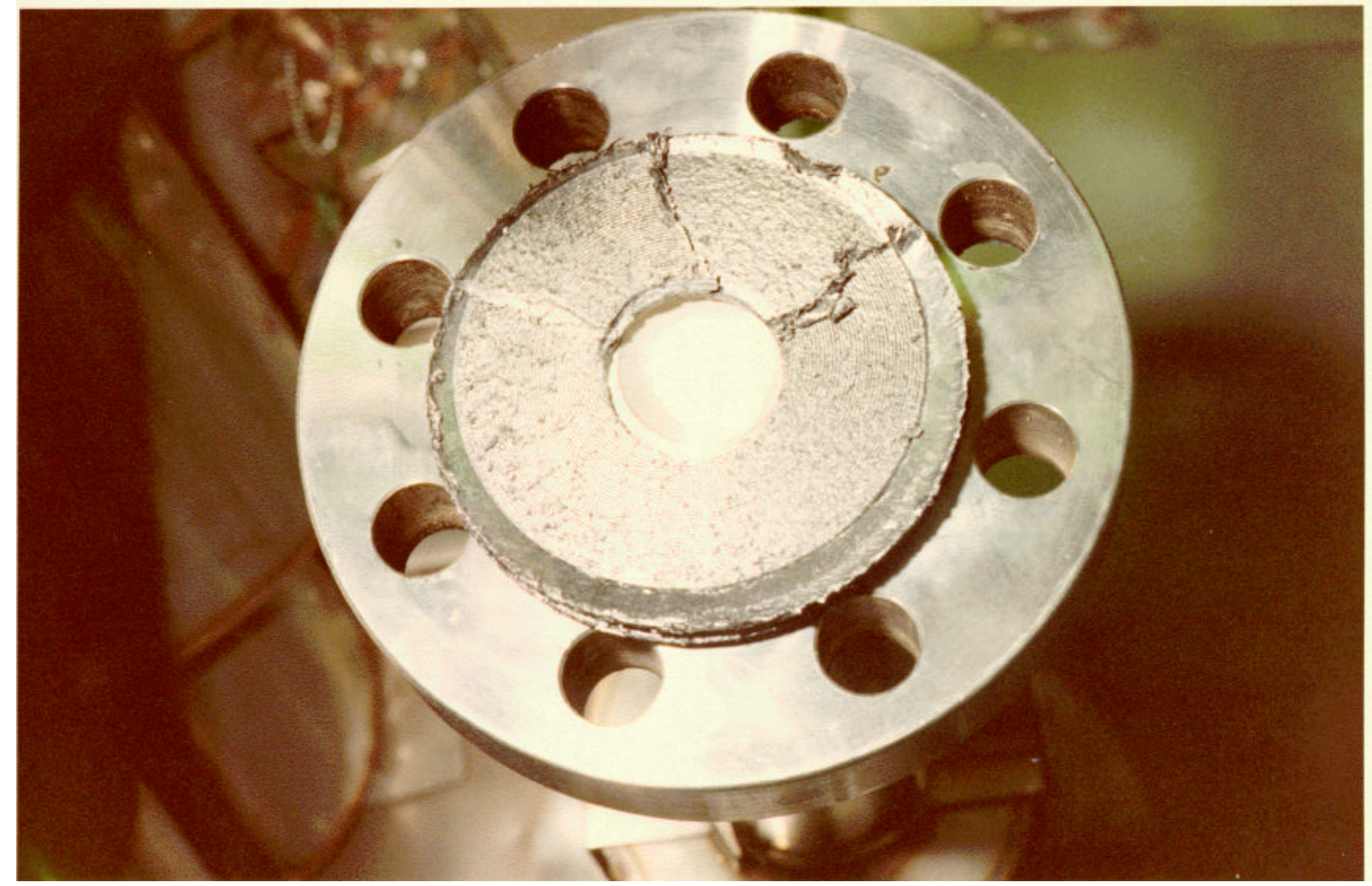

Figure A-11. The west calcine product removal line plugged with calcine prior to decontamination (81-5542). 


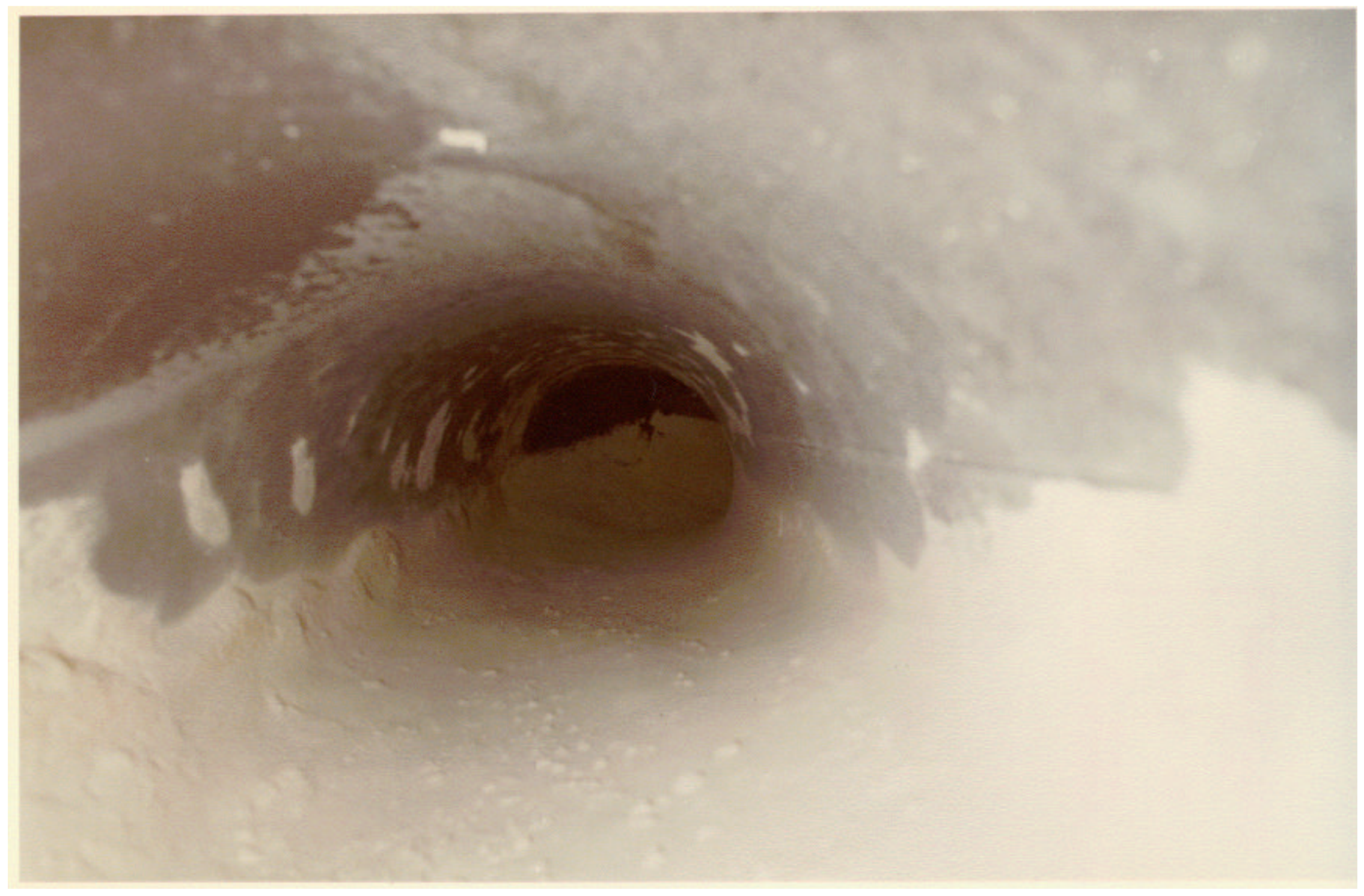

Figure A-12. Off-gas line downstream of cyclone vessel with 3 to 4 inches of calcine in the bottom of the 16-inch pipe (81-5540). 


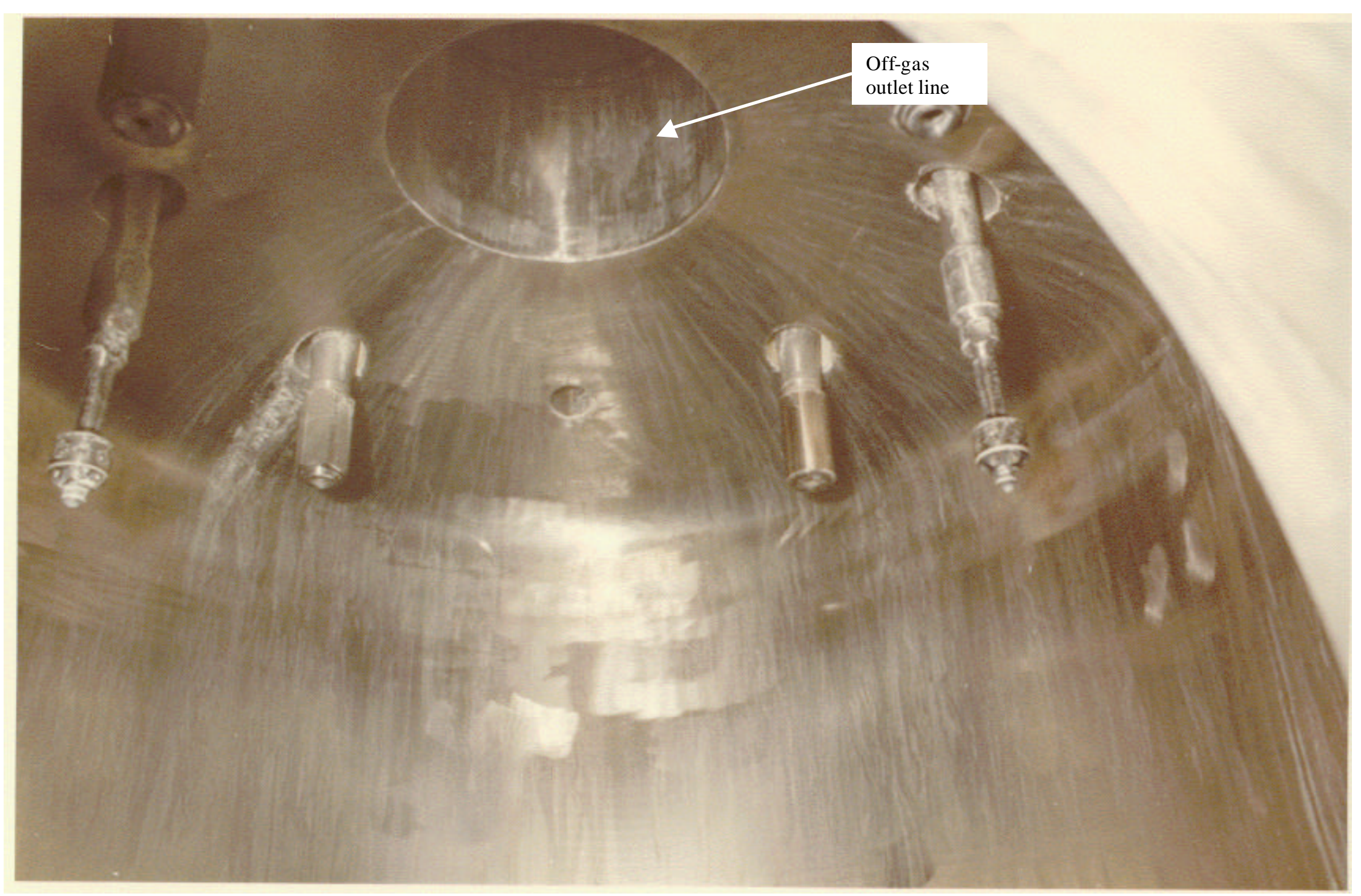

Figure A-13. Upper portion of the quench tower (VES-NCC-109) before decontamination. The vessel interior walls were relatively clean before decontamination. The off-gas outlet and the quench and decontamination nozzles are visible in the photograph (81-5572). 


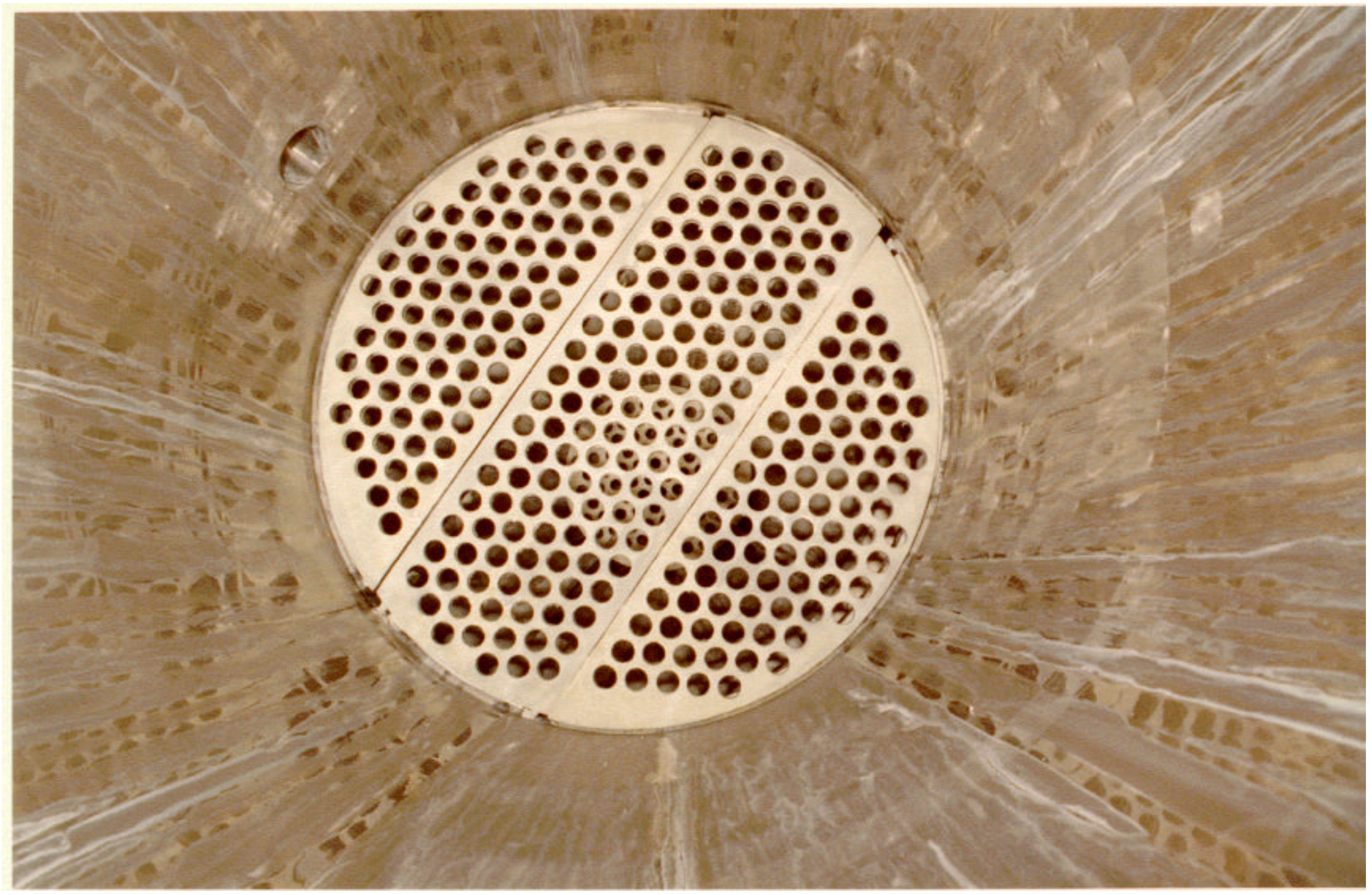

Figure A-14. Lower portion of the quench tower. The vessel was relatively clean prior to decontamination. Some streaks of dried quench solution residue are visible on the walls (81-5564). The Calciner off-gas distribution plate is visible in the bottom of the vessel. 


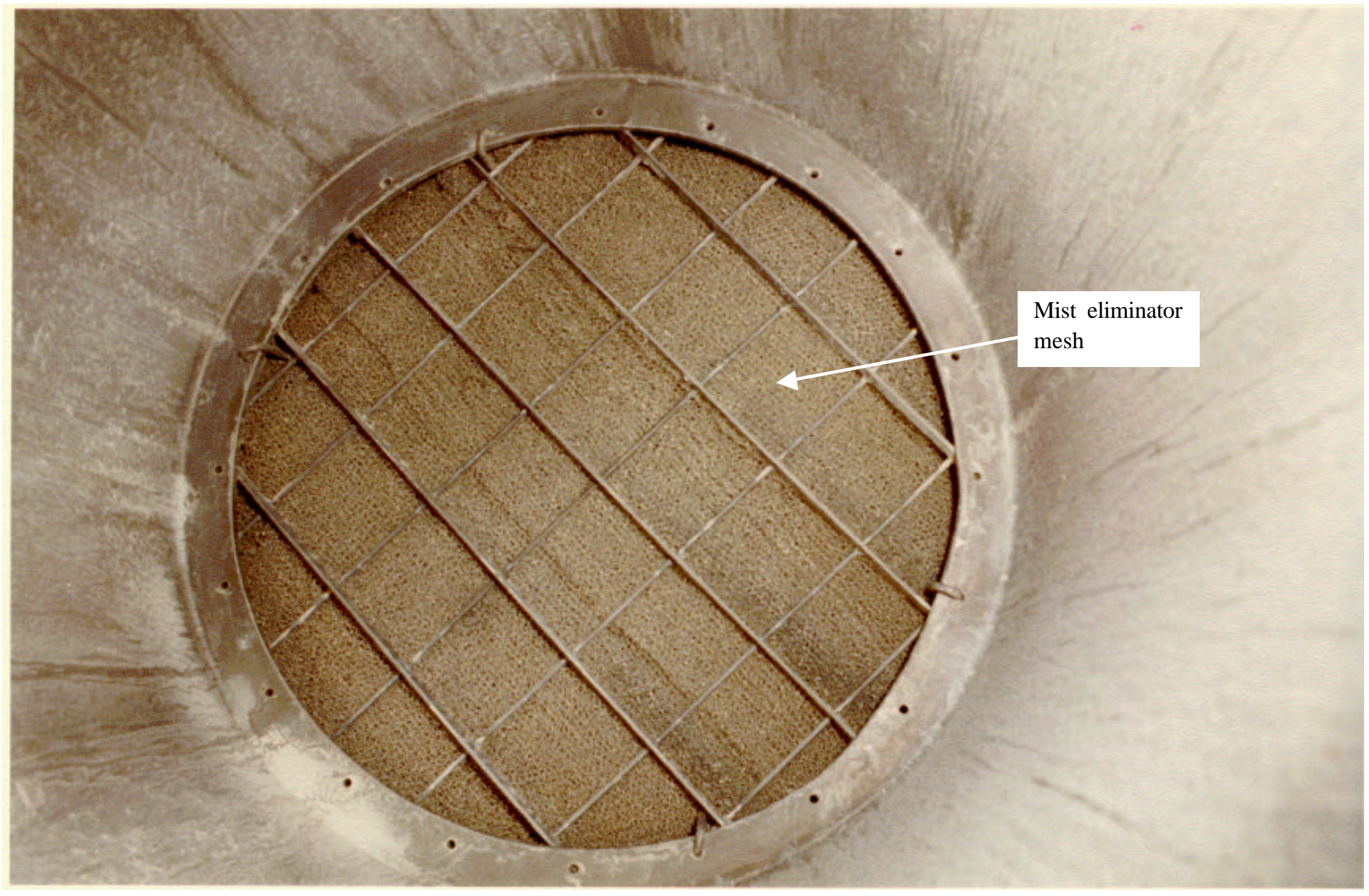

Figure A-15. Upper portion of knockout drum (VES-NCC-111) before decontamination. Some white streaks are visible on the vessel walls from dried quench solution prior to decontamination (81-5560). 


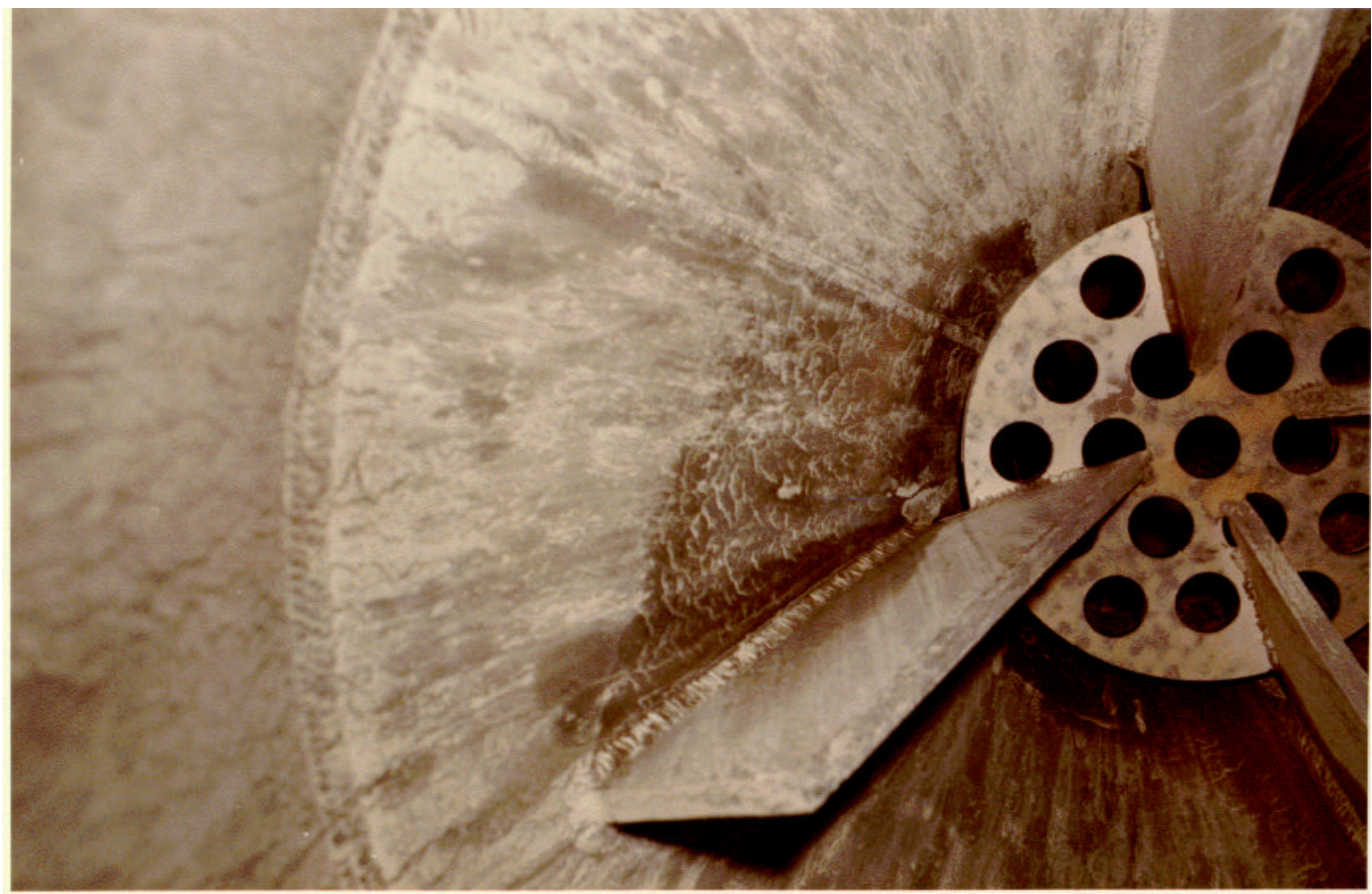

Figure A-16. Lower portion of knockout drum (VES-NCC-111) prior to decontamination. There was no calcine accumulation on the baffles or catch plate in the bottom of the vessel (81-5570). 


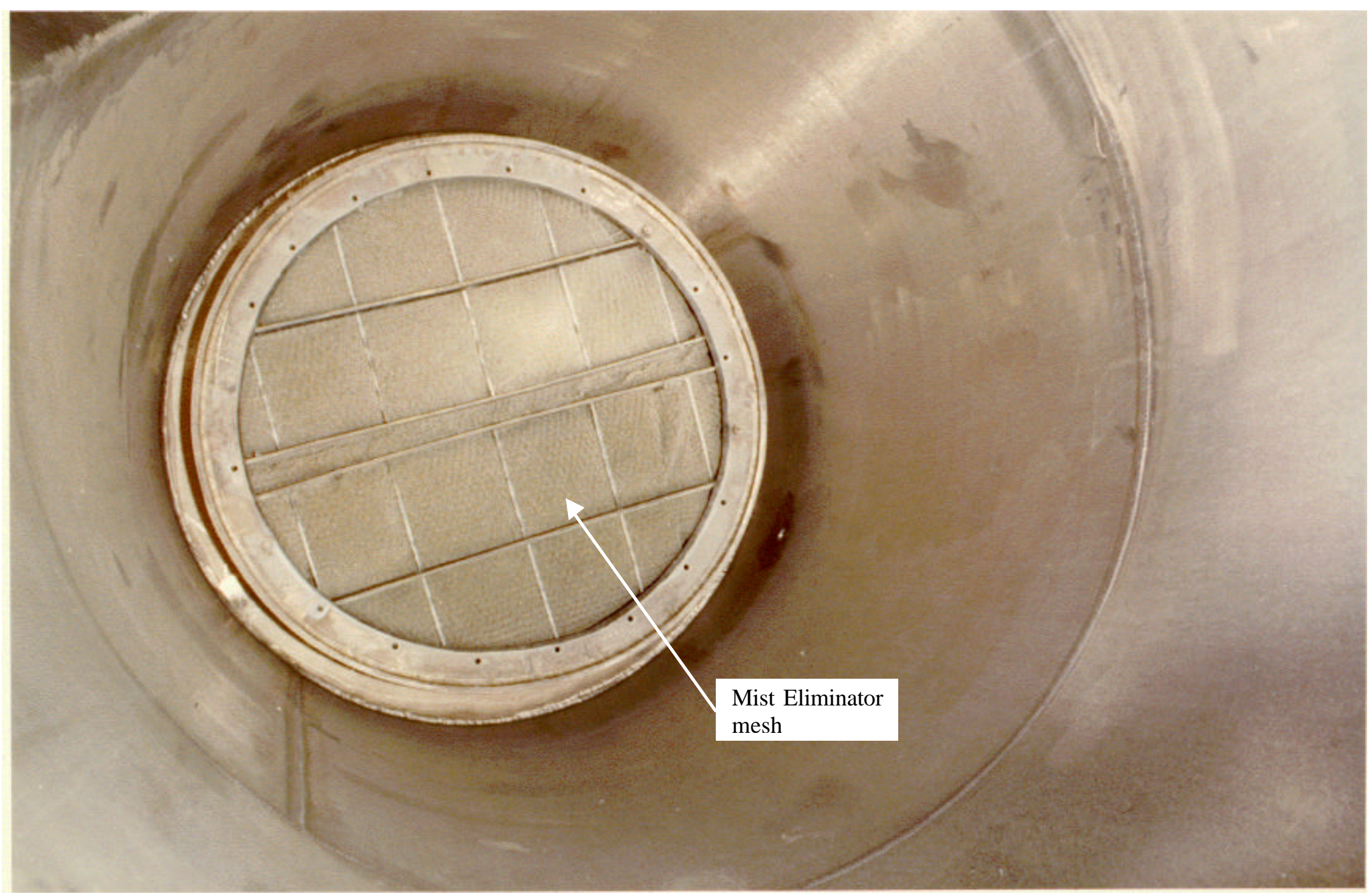

Figure A-17. View of the upper portion of mist eliminator VES-NCC-110 and its outlet (second of two) mesh prior to decontamination. The mesh and vessel walls are clean with no indication of calcine accumulation (81-5565). 


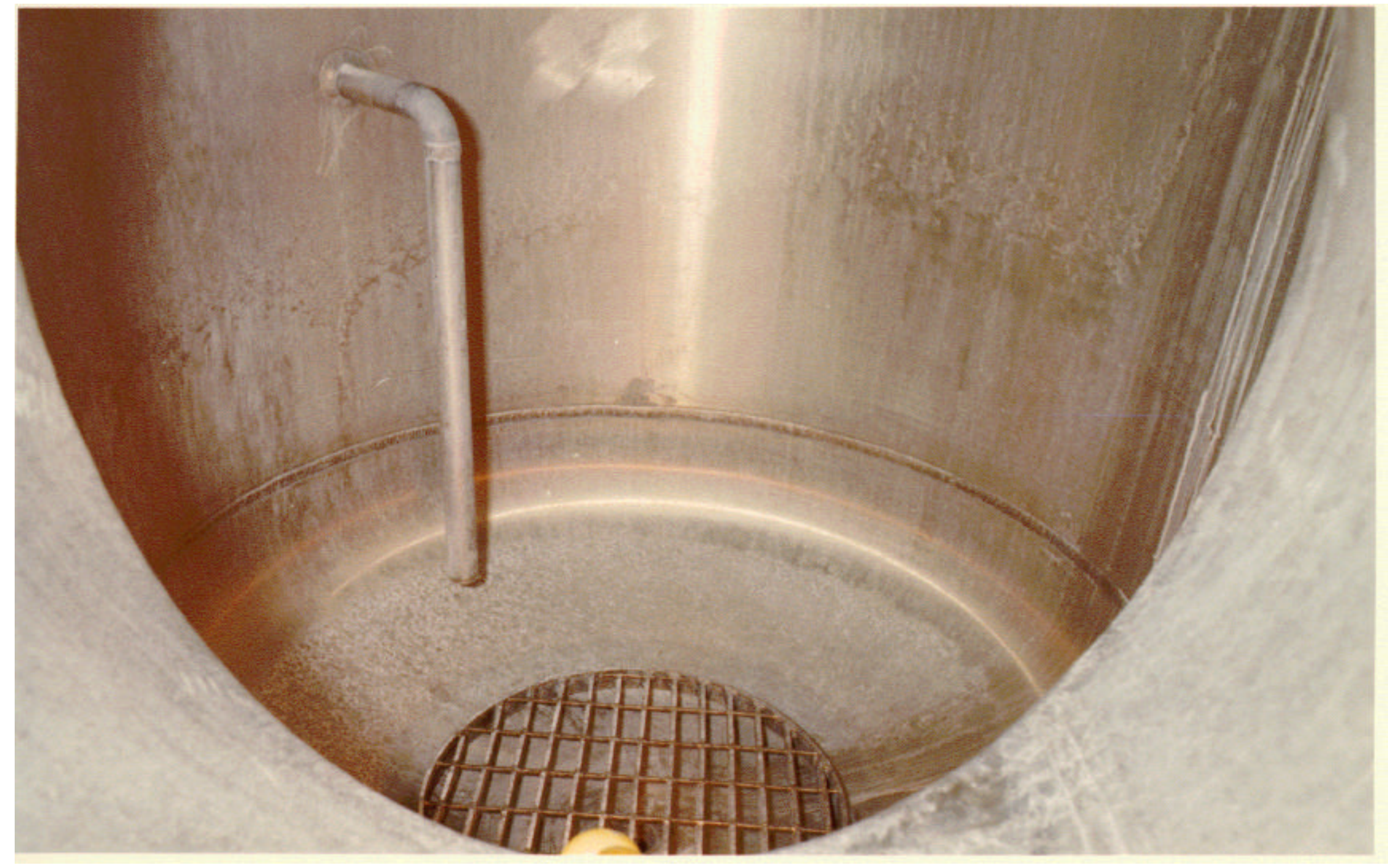

Figure A-18. View of the lower portion of mist eliminator (VES-NCC-110) before decontamination showing no calcine accumulation. The catch plate over the liquid drain line is in the lower part of the photograph (81-5568). 


\section{Appendix B}

\section{Post-decontamination NWCF Photographs}




\section{Appendix B}

\section{Post-decontamination NWCF Photographs}

Figure B-1. Upper portion of Calciner (VES-NCC-105) after decontamination ............................. B-2

Figure B-2. Calciner baffle plates after decontamination ........................................................

Figure B-3. Calciner baffle plates after decontamination .................................................... B-4

Figure B-4. Calciner baffle plate inspection plug after decontamination ................................... B-5

Figure B-5. Calciner fluidizing air distributor grid after decontamination .................................... B-6

Figure B-6. Calciner fluidizing air distribution plenum after decontamination .............................. B-7 


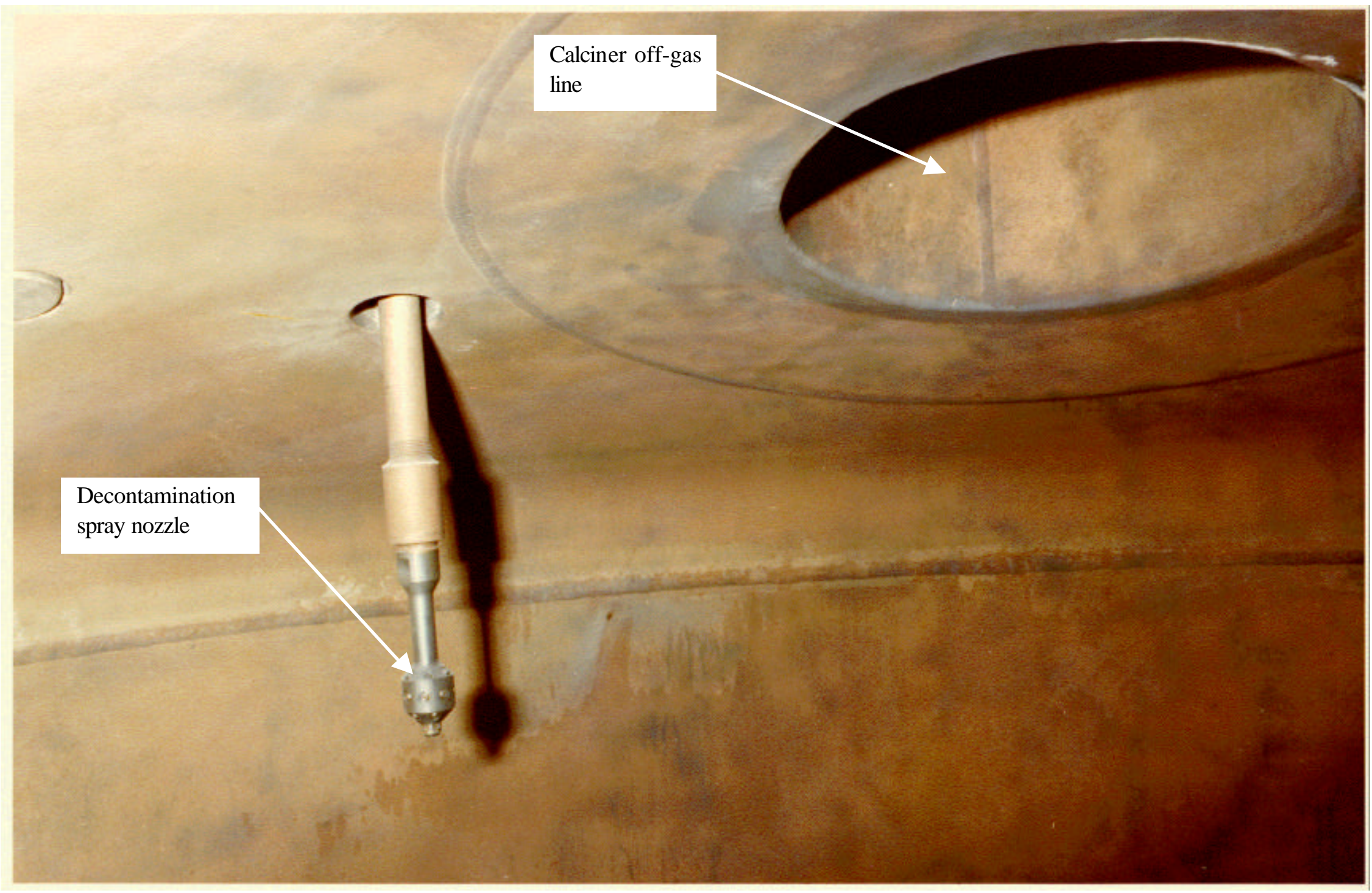

Figure B-1. Upper portion of the Calciner vessel, above the baffle plates, after the decontamination showing a virtually clean vessel. A comparison of this photograph with Figures A-2 and A-3 shows a dramatic reduction in calcine on the interior surfaces resulting from the decontamination (82-254). 


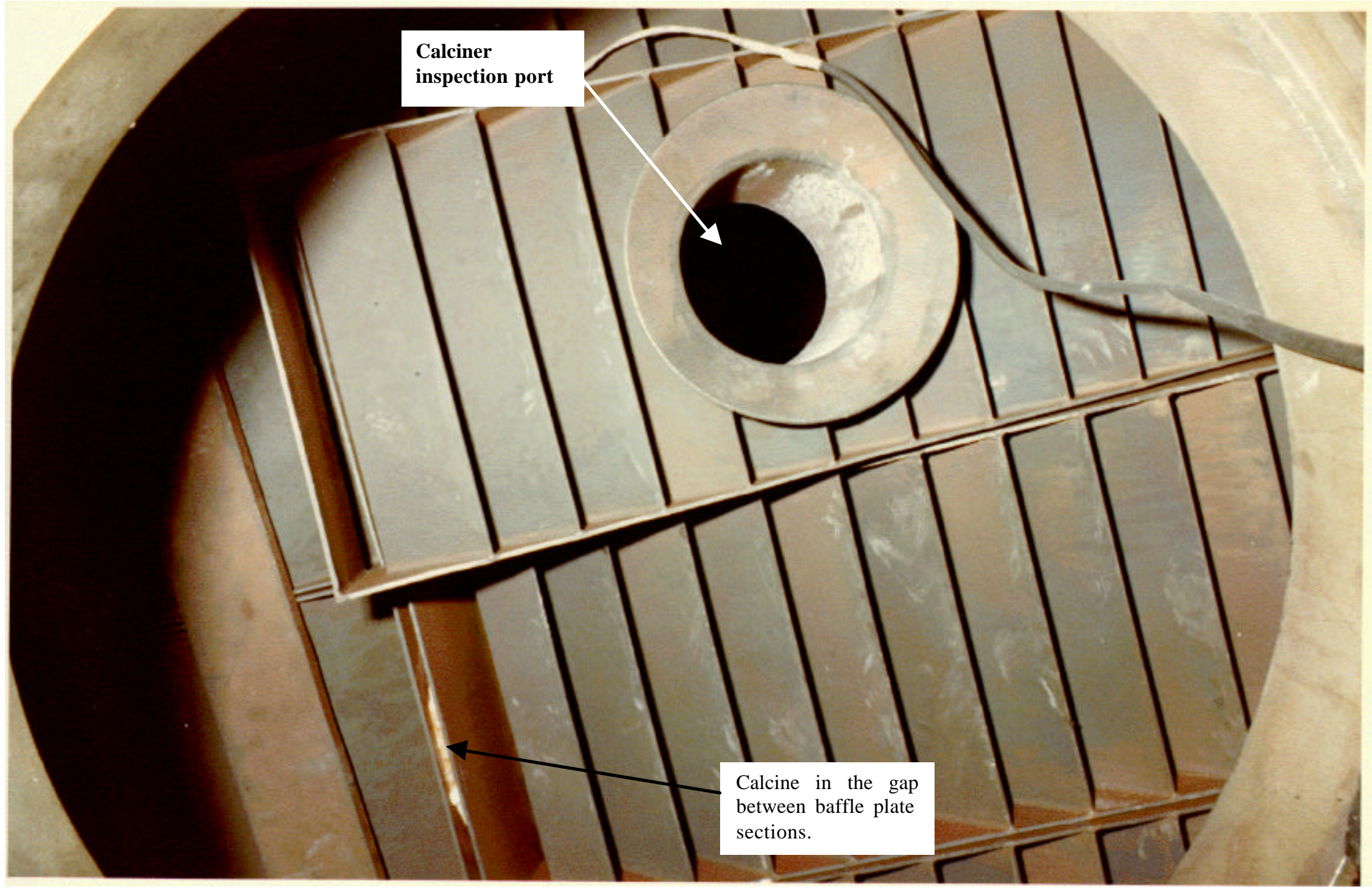

Figure B-2. View of the upper surfaces of the Calciner baffle plates after decontamination (82-255). This photograph shows most of the calcine present prior to the decontamination is gone (compare with Figure A-4). However, some calcine remains in the gaps between the baffle plate sections. The hole in the baffle plate is an inspection port and is normally plugged during Calciner operation (see figure B-4 for baffle plug). 


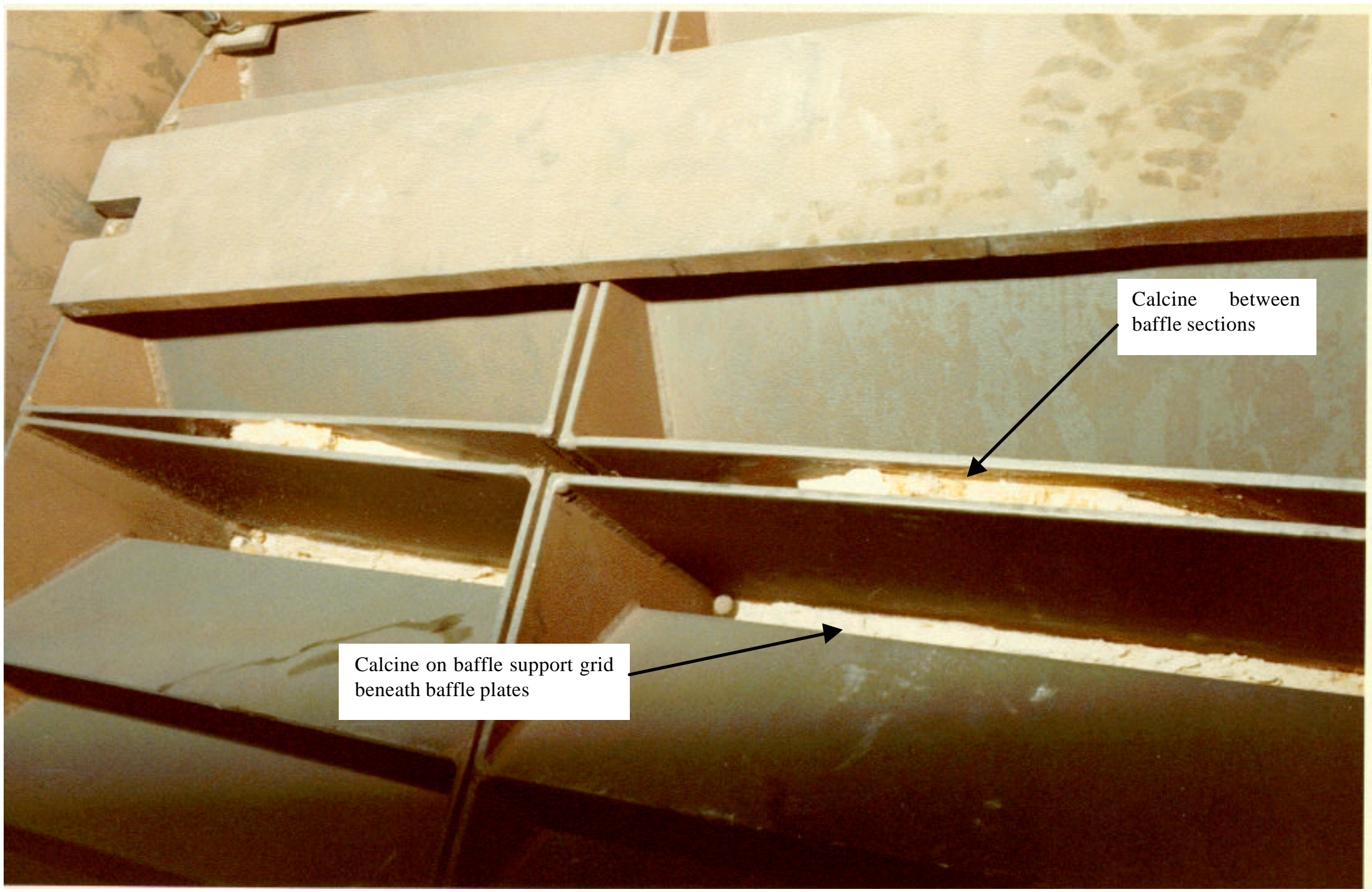

Figure B-3. Close-up view of Calciner baffle plates after decontamination showing calcine remaining between the baffle plate sections and on the baffle support grid beneath the section joints. The baffle supports were modified to eliminate the calcine residue seen in this picture (82-258). 


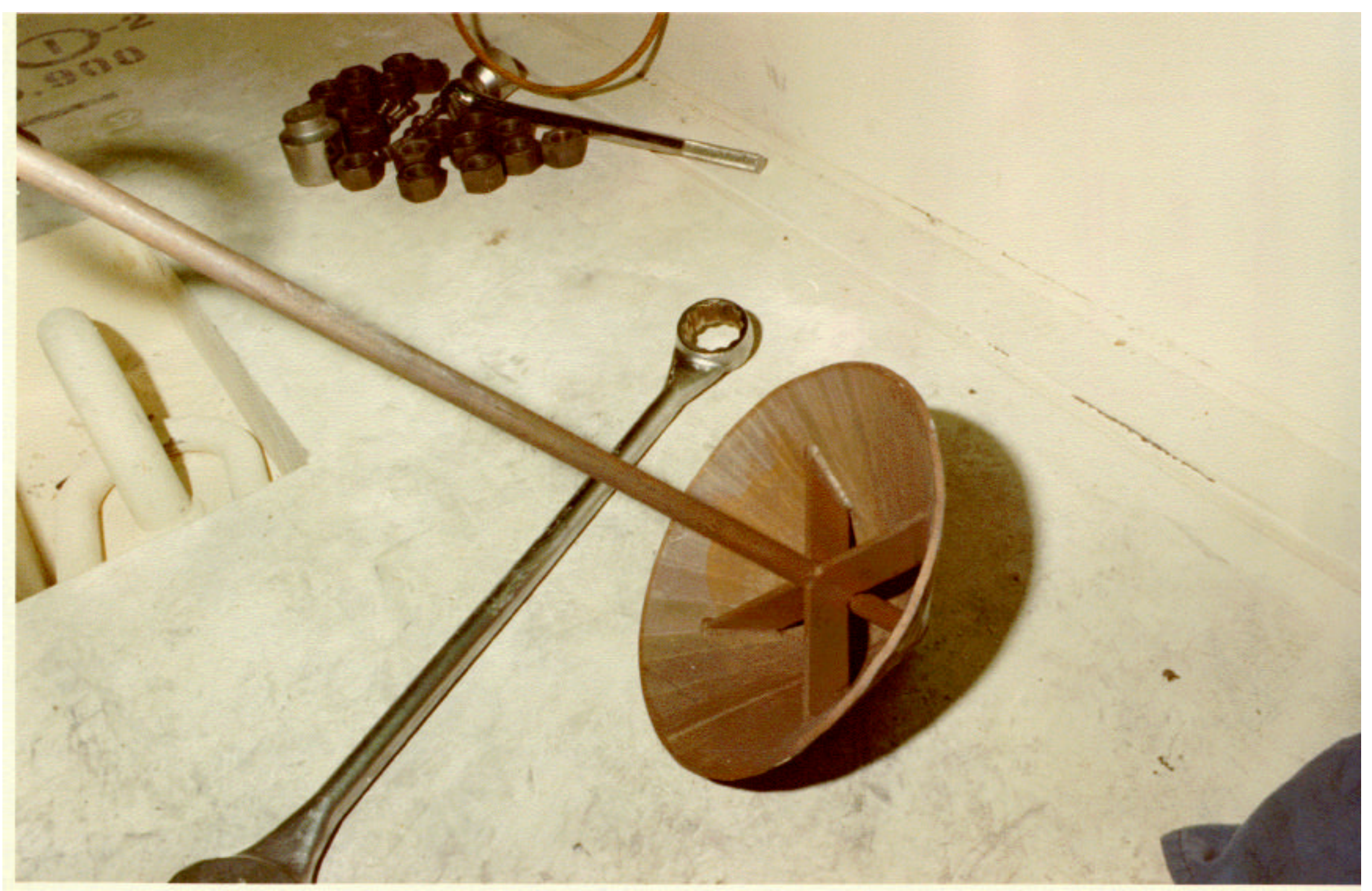

Figure B-4. View of the Calciner baffle plate inspection plug following decontamination. The plug is free of calcine. Compare with Figure A-5 for the predecontamination condition of plug when it was filled with calcine (82-246). 


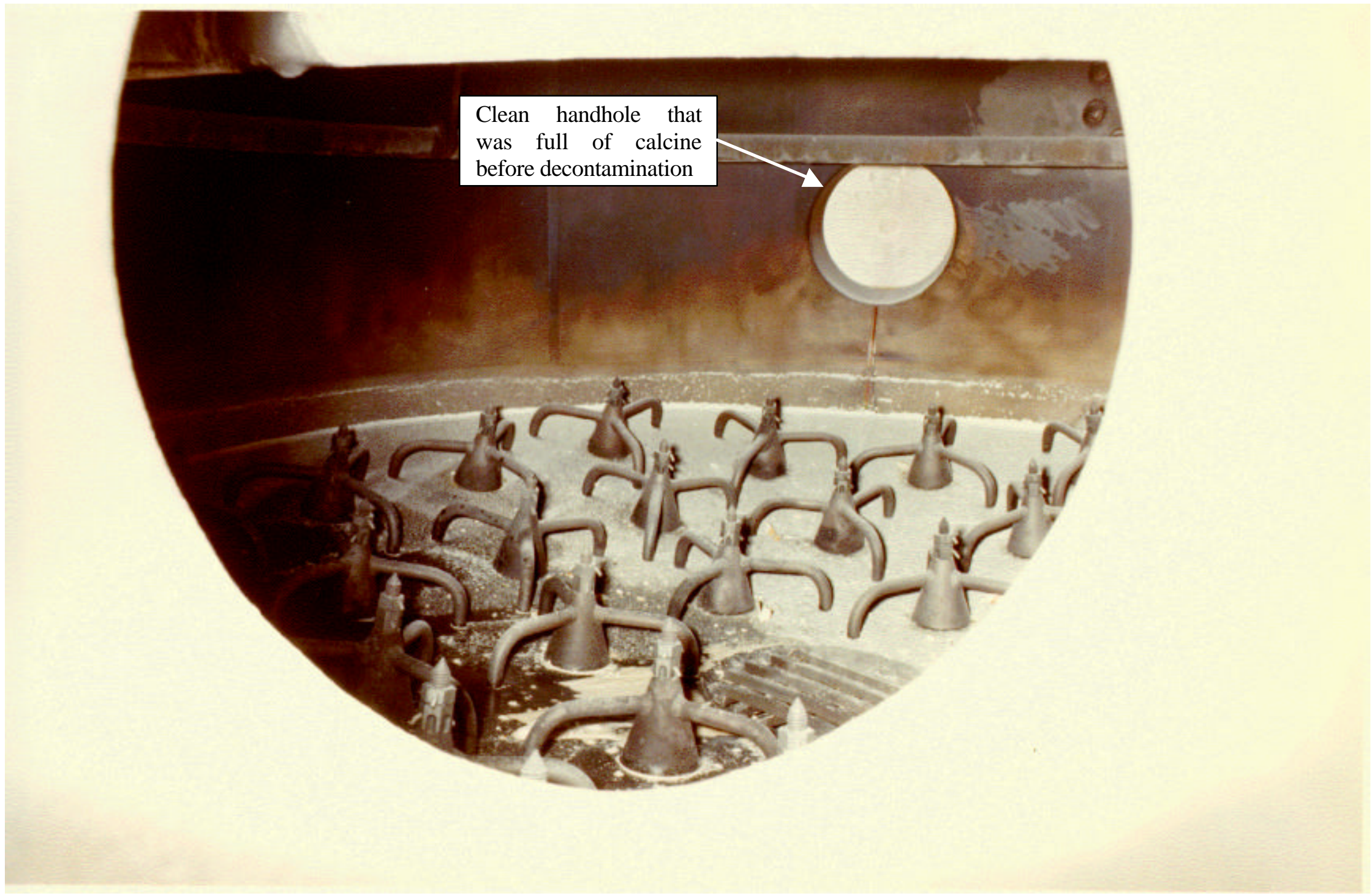

Figure B-5. View of the Calciner fluidizing air distributor grid after decontamination. The bulk of the calcine that was present prior to decontamination is gone (compare with Figures A-7 and A-8 for the pre-decontamination view). The distributor is clean with bare metal showing in some areas. A very thin layer (less than? inch) of calcine residue and a few small chunks remain in other areas (82-263). 


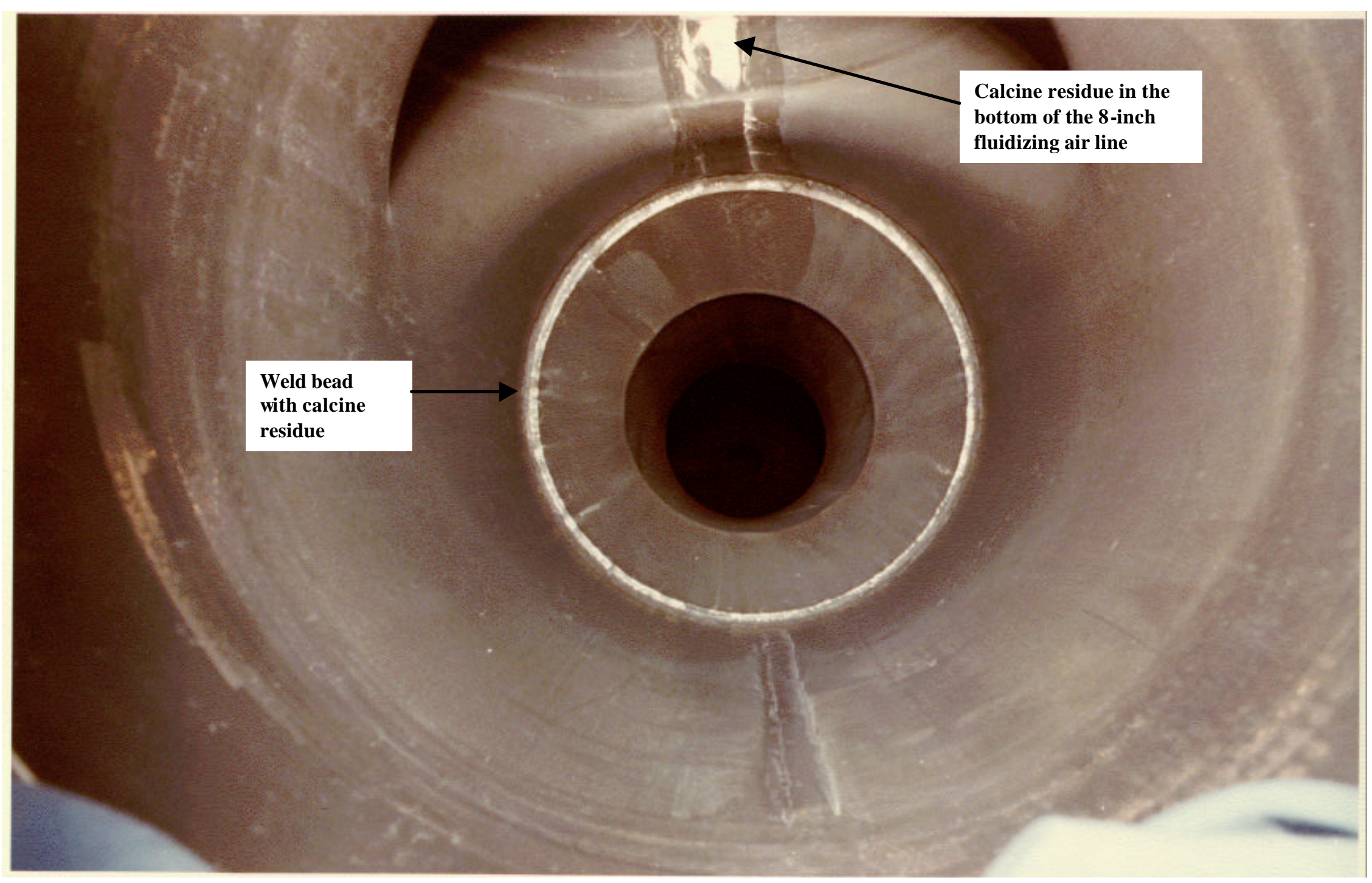

Figure B-6. View of the fluidizing air distribution plenum following the decontamination. Most of the calcine that was in the plenum prior to decontamination is gone. There is some calcine residue in the bottom of the fluidizing air line, and a very small amount on a weld bead in the bottom of the plenum. Compare with Figure A-10 for condition of plenum prior to decontamination. Additional decontamination nozzles were added to the fluidizing air line to eliminate the residue shown in this picture (82-267). 